Article

\title{
Running across the Silurian/Devonian Boundary along Northern Gondwana: A Conodont Perspective
}

\author{
Annalisa Ferretti ${ }^{1, * \mathbb{C}}$, Maria Giovanna Corriga ${ }^{2}$, Ladislav Slavík $^{3}$ and Carlo Corradini ${ }^{2} \mathbb{C}$ \\ 1 Department of Chemical and Geological Sciences, University of Modena and Reggio Emilia, Via Campi 103, \\ I-41125 Modena, Italy \\ 2 Department of Mathematics and Geosciences, University of Trieste, Via Weiss 2, I-34128 Trieste, Italy; \\ corrigamaria@hotmail.it (M.G.C.); ccorradini@units.it (C.C.) \\ 3 Institute of Geology of the Czech Academy of Sciences, Rozvojová 269, 16500 Prague, Czech Republic; \\ slavik@gli.cas.cz \\ * Correspondence: ferretti@unimore.it
}

check for

updates

Citation: Ferretti, A.; Corriga, M.G.;

Slavík, L.; Corradini, C. Running

across the Silurian/Devonian

Boundary along Northern

Gondwana: A Conodont Perspective.

Geosciences 2022, 12, 43. https://

doi.org/10.3390/geosciences12010043

Academic Editors: Emanuela

Mattioli, Maria Helena Henriques

and Jesus Martinez-Frias

Received: 29 November 2021

Accepted: 10 January 2022

Published: 17 January 2022

Publisher's Note: MDPI stays neutral with regard to jurisdictional claims in published maps and institutional affiliations.

Copyright: (c) 2022 by the authors. Licensee MDPI, Basel, Switzerland. This article is an open access article distributed under the terms and conditions of the Creative Commons Attribution (CC BY) license (https:// creativecommons.org/licenses/by/ $4.0 /)$.

\begin{abstract}
The Global Stratotype Section and Point (GSSP) of the Silurian/Devonian boundary, Lower Devonian Series and Lochkovian Stage was formally placed in 1977 at Klonk, in the Czech Republic, at the first appearance of the graptolite Uncinatograptus uniformis uniformis (Přibyl). However, since then, correlation of this limit has been often hampered in carbonate facies where graptolites are uncommon or totally absent. A large calcareous deposition occurred at the Silurian/Devonian boundary along the northern and peri-Gondwana margin, thus representing an ideal location to select and test a possible additional biostratigraphic marker of the limit among conodonts. The first appearance of Caudicriodus hesperius almost simultaneously at the base of the Devonian in Bohemia, the Carnic Alps, Sardinia, Morocco and elsewhere indicates that this taxon is the conodont that best approximates the beginning of the Period. The first or last appearance of other species (e.g., Ozarkodina confluens, Zieglerodina klonkensis, Z. remscheidensis and Caudicriodus woschmidti) may help to recognise the boundary as well.
\end{abstract}

Keywords: chronostratigraphy; biostratigraphy; correlation; Palaeozoic; Silurian/Devonian GSSP

\section{Introduction}

Graptolites and conodonts represent the best biostratigraphical tools for the Silurian and the Devonian, and most of the Stage limits of both Periods have been traditionally placed referring just to those fossil groups. However, graptolites mainly characterise organic-rich pelitic facies (sensu [1]) where, unluckily, conodonts are generally absent, whereas conodonts dominate in calcareous settings where graptolites are commonly lacking. This makes a precise tuning between conodont and graptolite biozonation schemes difficult, unless mixed lithologies, i.e., intercalations of black shales within limestones and viceversa, are present in the investigated succession. Some of the graptolite/conodont biostratigraphical zonation schemes already proposed (e.g., [2-14]) have also tried to establish a comparison with other fossil groups (e.g., chitinozoans, dacryoconarids, trilobites, crinoids, spores, armoured fishes, acanthodians, macroplants, ammonoids, ostracodes, sharks, etc.) in an attempt to provide a connecting "bridge" between conodont and graptolite data (Figure 1) [7,15].

The first appearance datum of the graptolite Uncinatograptus uniformis uniformis (Přibyl) has been chosen to define the Silurian/Devonian boundary, and its Global Boundary Stratotype Section and Point (GSSP) has been formally located in the Klonk section, Czech Republic [16], palaeogeographically placed at that time along northern Gondwana. However, for the reasons discussed above, the Silurian/Devonian limit can be easily followed by the marker graptolite taxon in siliciclastic facies, but it becomes hardly applicable in calcareous dominated settings. 


\begin{tabular}{|c|c|c|c|c|c|c|c|c|c|c|}
\hline $\begin{array}{l}\text { Age } \\
\text { (Ma) }\end{array}$ & PERIOD & \multicolumn{2}{|c|}{ EPOCHIAge } & $\begin{array}{l}\text { GRAPTOLITE } \\
\text { ZONATION }\end{array}$ & $\begin{array}{l}\text { CONODONT } \\
\text { ZONATION }\end{array}$ & $\begin{array}{c}\text { CHITINOZOAN } \\
\text { ZONATION }\end{array}$ & \begin{tabular}{|c|} 
SPORE \\
ZONATION \\
\end{tabular} & $\begin{array}{l}\text { ARMORED } \\
\text { FISH } \\
\text { ZONATION }\end{array}$ & $\begin{array}{l}\text { ACANTHO- } \\
\text { DIAN } \\
\text { ZONATION }\end{array}$ & $\begin{array}{l}\text { MACRO- } \\
\text { PLANTS }\end{array}$ \\
\hline \multirow{2}{*}{ 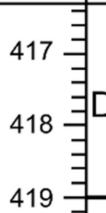 } & \multirow{2}{*}{ DEVONIAN } & \multirow{2}{*}{$\begin{array}{l}> \\
-d \\
\alpha \\
\sigma \\
w\end{array}$} & \multirow{2}{*}{${ }_{419.0}^{\frac{c}{\frac{0}{0}}}$} & \multirow{2}{*}{$\begin{array}{c}\text { Uncinatograptus } \\
\text { uniformis } \\
\text { uniformis }\end{array}$} & Caudicriodus postwoschmidti & \multirow[t]{2}{*}{$\begin{array}{l}\text { Fungochitina } \\
\text { lata }\end{array}$} & \begin{tabular}{|c|} 
Emphanisporites \\
micromatus- \\
Streelispora \\
newportensis \\
\end{tabular} & \multirow{2}{*}{$\begin{array}{c}\text { Rhinopteraspis } \\
\text { Phialaspis, } \\
\text { Protopteraspis, } \\
\text { Pteraspis } \\
\text { rostrata }\end{array}$} & \multirow{3}{*}{$\begin{array}{l}\text { Nostolepis } \\
\text { minima } \\
\text { Trimerolepis } \\
\text { timanica }\end{array}$} & \multirow[t]{2}{*}{ Zosterophyllum } \\
\hline & & & & & Caudicriodus hesperius & & \multirow{4}{*}{ NOT ZONED } & & & \\
\hline \multirow{3}{*}{420 寻 } & \multirow{3}{*}{ SILURIAN } & \multirow{3}{*}{ 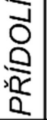 } & & \multirow{3}{*}{$\begin{array}{c}\text { Istrograptus } \\
\text { transgrediens / } \\
\text { " } M \text { ". perneri }\end{array}$} & \multirow{3}{*}{$\begin{array}{c}\text { Upper Oul. el. detortus/ } \\
\text { Z. Klonkensis }\end{array}$} & \multirow{3}{*}{$\begin{array}{l}\text { Angochitina } \\
\text { superba }\end{array}$} & & & & \\
\hline & & & & & & & & & $\begin{array}{c}\text { Poracanthodes } \\
\text { punctatus }\end{array}$ & \\
\hline & & & & & & & & & $\begin{array}{c}\text { Nostolepis } \\
\text { gracilis }\end{array}$ & \\
\hline
\end{tabular}

Figure 1. Main biostratigraphical markers across the Silurian/Devonian boundary. Modified after Becker et al. (2020) [15] and Melchin et al. (2020) [7].

Several additional sections, located in the same geographical region of the GSSP, expose calcareous sediments across the Silurian/Devonian boundary, documenting a variety of depositional settings, from very shallow water to moderately deep or deep-shelf environments [17]. The literature from some of these areas report fossil names, the validity and age-ranges, which are in strong need of a deep taxonomic revision. For some other sites, including the type area (i.e., Bohemia, Carnic Alps, Sardinia and Morocco) [11,17-21], recent conodont studies, integrating new sampling with historical collections, have been run in the attempt to provide a precise updating both of the biostratigraphy and the taxonomy of the rich conodont associations there reported.

The aim of this contribution is to integrate and correlate these new conodont data with the old literature inside and outside the northern Gondwana region (Figure 2) in an attempt to provide a global synthesis on the conodont occurrences along northern Gondwana at the Silurian/Devonian boundary and offer an efficient tool for locating the boundary level in carbonate facies.

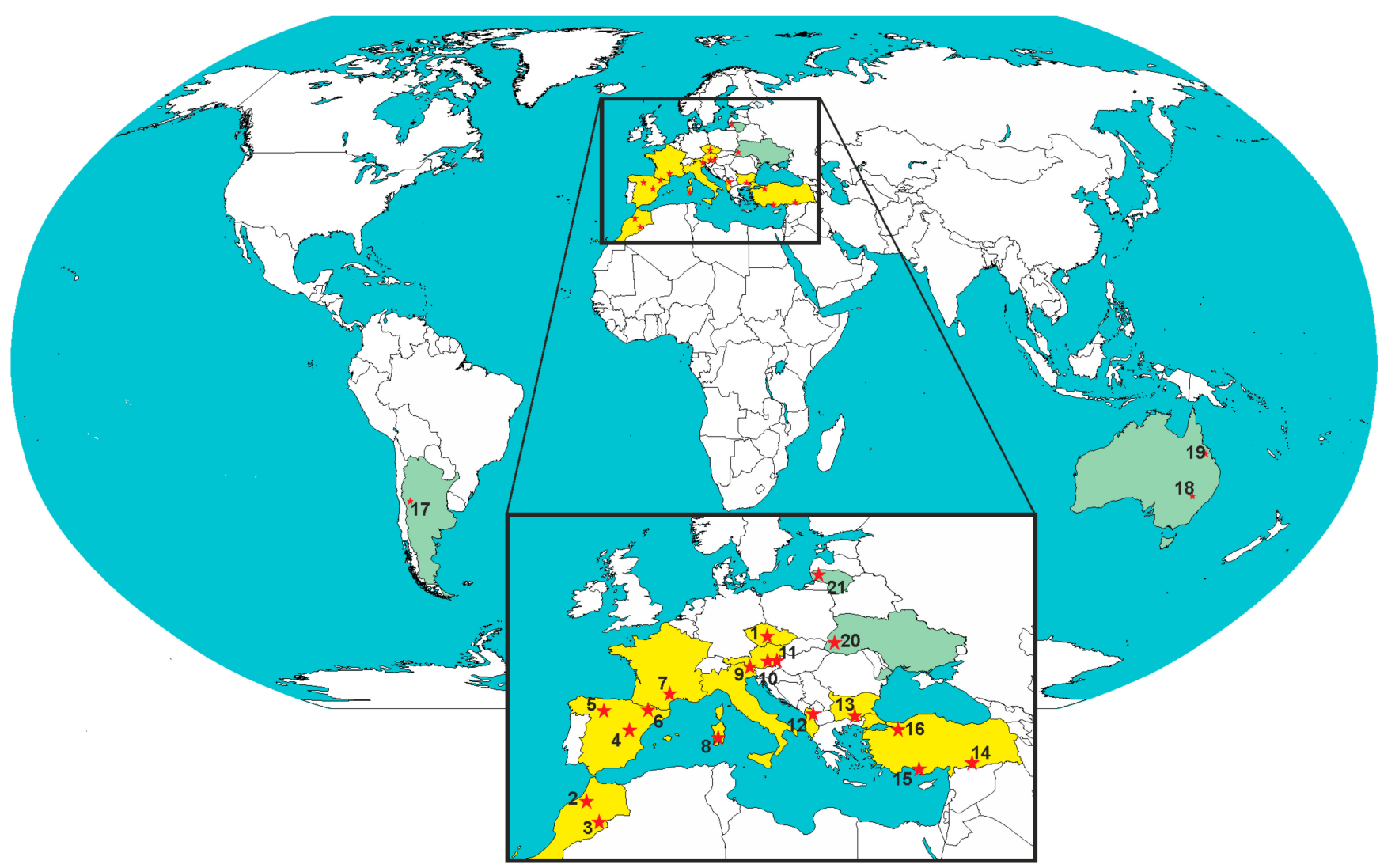

Figure 2. Main areas investigated in this paper. Yellow: northern Gondwana regions; green: other 
studied areas. Red stars refer to conodont localities analysed in this study, labeled according to the order in which they are discussed in the text. 1. Barrandian (Czech Republic); 2. Western Meseta (Morocco); 3. Tafilalt (Morocco); 4. Iberian Chain (Spain); 5. Palentine Domain (Spain); 6. Pyrenees (Spain); 7. Montagne Noire (France); 8. Sardinia (Italy); 9. Carnic Alps (Italy and Austria); 10. Graz Paleozoic (Austria); 11. Burgenland (Austria); 12. Albania; 13. Bulgaria; 14. Arabian Plate (Turkey); 15. Taurides (Turkey); 16. Pontides (Turkey); 17. Precordillera (Argentina); 18. New South Wales (Australia); 19. Broken River (Australia); 20. Podolia (Ukraine); 21. Lithuania.

\section{Palaeogeography across the Silurian/Devonian Boundary}

The present-day distribution of Silurian/Devonian basin fragments in modern geographical configurations is the end result of intensive orogenic and drifting/rifting episodes. Through a combination of studies on fauna and flora distribution (e.g., [22-30]), the application of sedimentological criteria combined with palaeoclimatical approaches and the measurement of palaeomagnetic signals (see, among others, [31-42]), and by the analysis of structural/geodynamical patterns and sea-level fluctuations (e.g., [43-46]), diverse past palaeogeographical configurations have been proposed (e.g., [47,48]).

Most of the sectors comprising peri-Gondwana and northern Gondwana are now included in South-Central Europe (Czech Republic, South Germany, Spain, Portugal, France, Austria, Italy and probably Romania), North Africa (Morocco, Algeria, Tunisia, Libya, Niger and Egypt), the Middle East (Turkey, Syria, Jordan, Iraq and Saudi Arabia), Florida and parts of southeastern USA [27]. Sequences of different thicknesses were deposited, whose difference in relative completeness are due to either non-deposition or to erosion. Marked variations in the dominant lithofacies are attributed to the various palaeogeographical positions of the basin fragments during the Silurian-Devonian interval.

The transition to the Devonian, $419 \mathrm{Ma}$ ago, led to completion the general process of continental plate convergence that had characterised the Silurian Period [7]. Most continental areas occupied one hemisphere, whereas the other was mainly represented by water ("Proto-Pacific" or Panthalassa Ocean) [15]. Laurussia had in fact originated from the merging of Laurentia and Baltica. Siberia and Kazakstania were located at nearby settings (Figure 3). This large continental block was bordered in the southern part by remnants of two oceans, which were going soon to be closed: the Iapetus Ocean to the West and the Rheic Ocean to the East, leaving the place to the Proto-Tethys.

Palaeogeographical maps commonly depict a continuous continental ribbon at highest southern latitudes, having present-day geographical areas of South-Central Europe and North Africa at the meridional flank of the Rheic Ocean. However, their relative positioning has been subject to several shifts and re-assemblages, moving from a general amalgamation (see a summary in [49-51]) to a "palaeogeographical splitting" in a series of microterranes (e.g., [52,53]). Whatever was the precise location of these sectors at that time, it is unanimously accepted that a strong connection was active between all areas belonging to, or close to, the northern Gondwana margin during Silurian and Devonian times.

The palaeogeographical configuration adopted in this study (Figure 3) follows Scotese (2014) [54] in placing all areas of northern Gondwana along a continuous margin at high latitudes, with the Prague Synform (Barrandian area, Czech Republic), where the GSSP for the Silurian/Devonian boundary has been selected [16], at lowermost latitudes and in a promontory position. 

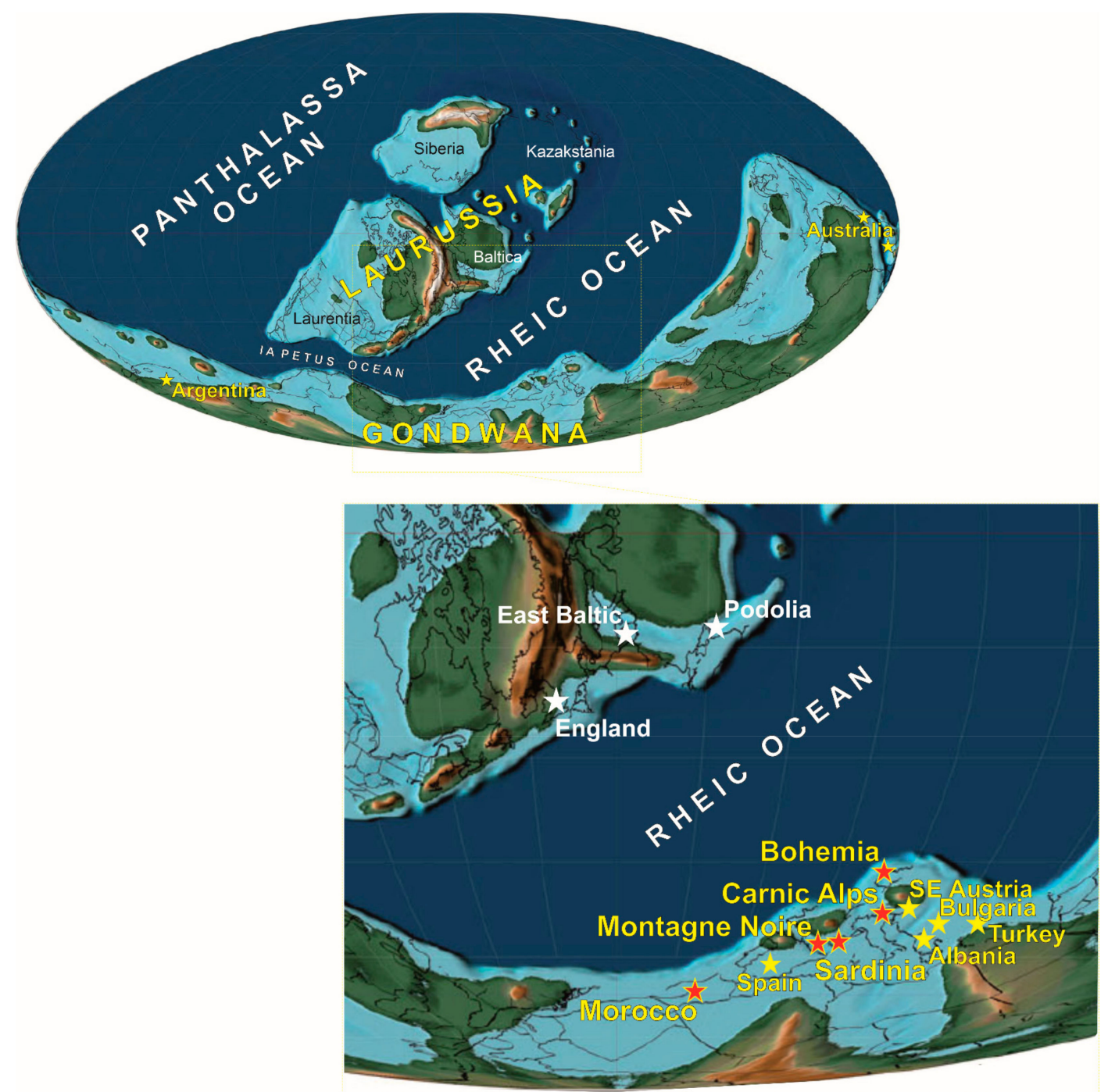

Figure 3. Palaeogeographical distribution of published conodont records across the Silurian/Devonian boundary along northern Gondwana. Stars indicate data analysed in the present paper, with red stars pointing to collections studied directly by the Authors. Palaeogeographical reconstruction after Scotese (2014) [54].

\section{The Silurian/Devonian Boundary}

Sedgwick and Murchison formally introduced the Devonian System in 1839 in southwestern England, following suggestions provided by Londsdale, who had first proposed the name Devonian [55]. Regarding System boundaries, an exhaustive history on the Silurian/Devonian limit was recently summarised by Becker et al. (2020) [15], who remarked how, following the British graptolite school and the occurrences there in the Ludlow Bone Bed, the extinction of graptolites was initially regarded to be the marker for locating the start of the Devonian. It was then realised that graptolites were not extinct, and after a detailed and time-consuming search for the best marker(s) of the Silurian/Devonian boundary [16], it was decided to define the base of the Devonian on the first appearance of the graptolite Uncinatograptus uniformis uniformis and of the trilobites of the Warburgella rugulosa group. The GSSP for the Silurian/Devonian boundary, Lower Devonian Series and Lochkovian Stage was finally located $35 \mathrm{~km}$ southwest of Prague in the southwestern part of the Barrandian region (see below), specifically within Bed 20 in the Klonk section [16]. In the upper part of that bed, immediately above the limit, the occurrences of $U$. uniformis uniformis and $U$. uniformis angustidens (Prribyl) were recorded [56]. 
Conodonts are present as well in the Klonk section. However, in recent years some late Silurian-Early Devonian marker genera were subject to a taxonomic revision, as they were revealed to be a "waste-basket" of different lineages. As a consequence, a global reorganisation of the conodont biozonation schemes of the Silurian and the Devonian occurred (see a detailed discussion in [21]).

The appearance of the conodont genus Icriodus has been considered for a long time as equivalent to the start of the Devonian. In particular, the Caudicriodus woschmidti Zone was believed to represent the basal Devonian conodont zone. It should be noted, however, that some Authors, but not all, include the early representatives of the genus ("Icr." woschmidti Ziegler and "Icr." hesperius Klapper and Murphy) within the genus Caudicriodus Bultynck. Jeppsson (1988) [57] remarked that the occurrence of Caud. woschmidti slightly anticipates that of U. u. uniformis in many sections, but Corradini and Corriga (2012) [11] explained this apparent discrepancy as simply due to a facies control. Carls et al. (2007) [58] recognised in Caudicriodus hesperius the main species previously included within the early Lochkovian Caud. woschmidti, occurring together with other undetermined species of the same genus. Even if Caudicriodus hesperius enters slightly higher in the lower Lochkovian from the type locality, Carls et al. (2007) [58] elected this taxon as the conodont species closest to the Lower Devonian boundary. This opinion is mostly accepted among conodont workers, and the Caudicriodus hesperius Zone appears as the first conodont zone of the Devonian System in most conodont biozonation schemes.

\section{Silurian/Devonian Boundary Event, Carbon Isotope Excursion and Conodont Diversity}

The most important and worldwide event that marks the Silurian/Devonian boundary is based just on the first occurrence of the index graptolite Uncinatograptus u. uniformis. It was defined by Walliser (1985) [59] as the Silurian/Devonian Boundary Event. Later, this event was characterised as a marked environmental change [60] and some Authors considered this event as a pronounced extinction event (e.g., [61,62]). The Carbon Isotope Excursion (CIE) at the Silurian/Devonian boundary was described by Hladíková et al. (1997) [63] based both on the Silurian/Devonian GSSP at Klonk and its auxiliary stratotype at the Budňany rock section near Karlštejn in the Prague Synform. The excursion was later confirmed from many other sections around the stratotype area (e.g., [62,64]). Buggish and Mann (2004) [64] proposed worldwide carbon isotope stratigraphic trends across the Silurian/Devonian transition. Similar trends had already been documented in other periods and correlated world-wide (e.g., $[65,66])$. The onset of the CIE in the latest Přídolí, with the peak of the excursion at the boundary or in the earliest Lochkovian, was confirmed in many other areas of the world, e.g., [67-70] (Laurentia), [71-75] (East Baltica-Podolia and Lithuania), [76,77] (Carnic Alps). A possible driver can be considered the enhanced organic carbon burial of rapidly evolving terrestrial biota [71]. However, irrespective of various interpretations of likely triggers of the Silurian/Devonian boundary CIE, its correlation potential is large and can be roughly linked with the origin of the genus Icriodus that represents one of the most important events among Devonian conodont faunas-i.e., the Icriodus Event [78]. The oldest icriodid is found in the same bed with the FAD of $U$. $u$. uniformis, that is immediately followed by C. hesperius in the Prague Synform [21] - the conodont marker of the base of the Devonian. The Event well represents conodont response to the environmental change at the systemic boundary. With respect to conodonts, it is not an extinction event because the base of Lochkovian is characterised by a radiation in conodont taxa (mostly icriodids and ozarkodinids of genus Zieglerodina) that is reflected in both increased diversity and overall abundance of conodont faunas (cf. [78]).

The Silurian/Devonian CIE has, however, a misleading terminology. The excursion is often referred to in literature as the "Klonk Event". This name has its origin in the "Klonk Secundo-Unnamed Event" - a conodont event by Jeppsson (1998) [57] that corresponds to the origin of Oul. el. detortus in the Oul. el. elegans-Oul. e. detorta lineage. However, the taxon enters close to middle of the Přídolí, being ca 2 m.y. older than the Silurian/Devonian 
boundary. Therefore, the name of the original Silurian/Devonian Boundary Event by Walliser in relation to the CIE is preferred and recommended in this paper.

\section{Taxonomic Note}

The taxonomy of late Silurian and Early Devonian conodonts has been widely revised in the last twenty years, and several genera were proposed to discriminate part of the forms previously included in a "basket" genus or even in a single species. As example, form elements previously attributed to Spathognathodus steinhornensis remscheidensis Ziegler were later renamed Ozarkodina remscheidensis (Ziegler) in terms of natural species (multielement apparatus), which is now included in several species of the genus Zieglerodina (e.g., Z. remscheidensis, Z. planilingua (Murphy and Valenzuela-Ríos), Z. zellmeri Carls at al., Z. klonkensis Carls at al., Z. ivochlupaci Carls at al., Z. mashkovae (Drygant), Z. formosa (Drygant), Z. eladioi (Valenzuela-Ríos), Z. schoenlaubi Corradini et al., Z. petrea Hušková and Slavík, Z. camelfordensis (Farrell), Z. prosoplatys (Mawson et al.), etc.). This makes referring to fauna documented in old papers difficult, because we cannot convert the name $\mathrm{Oz}$. remscheidensis to the present species concept, unless for figured specimens that always represent a very minor part of the association. This is why in the various chapters of this paper we cannot sometimes provide further details, and we report the occurrence of "various species of Zieglerodina" or to Zieglerodina sp.

Other cases are easier to interpret, as there is a general agreement at specific level, but the same species is attributed by Authors to diverse genera, since some of the genera created are not accepted by some, or even the majority, of Authors. As an example, the former Icriodus woschmidti is named in different papers as Icriodus woschmidti, Caudicriodus woschmidti or Cypricriodus woschmidti. The same occurs for Oulodus elegans detortus (Walliser), also sometimes indicated as Delotaxis elegans detorta or even Oulodus detortus or Delotaxis detorta, with only limited taxonomical justification.

Additionally, the former multielement genus Ozarkodina is now subdivided into various genera and the genus name Ozarkodina is limited to a few species with a well-defined shape of the elements of the apparatus. Other species are now moved to various genera (Wurmiella, Zieglerodina, Walliserognathus, Ancyrodelloides, Lanea, Flajsella, etc.), and those that are not hosted in these new genera are generically attributed to "Ozarkodina".

\section{The Silurian/Devonian Boundary along the Northern Gondwana Margin}

The conodont distribution across the Silurian/Devonian boundary is dealed with in the following chapters, starting from the type of area. Then, the northern Gondwana sectors are discussed from West to East.

\subsection{Bohemia (Czech Republic)}

Unmetamorphosed Lower Palaeozoic rocks are part of the Teplá-Barrandian Unit (TBU), which is located in the central part of the Bohemian Massif [79]. This unit includes Neoproterozoic to Middle Devonian volcano-sedimentary rocks of the Prague Synform, which were subject to the Cadomian and Variscan orogenies [80]. The central part of the Prague Synform (also termed the Prague Basin) is an asymmetrical elliptical structural depression, which represents an erosional relic of Lower Palaeozoic volcanosedimentary successions [81,82].

The uppermost Silurian (Požáry Fm.) and the Silurian/Devonian boundary are characterised by lower subtidal to upper slope deposits and slope-to-basin-floor distal calciturbidites [83,84]. Volcanic activity gave rise to submarine elevations and triggered intense carbonate sedimentation around them during the late Silurian [85]. The almost continuous Silurian/Devonian sedimentation is testified by the onset of Lochkovian carbonate deposition, which represents the upper slope to toe-of-slope facies ranging from coarse crinoidal massive limestones to black-grey rhythmites with cherts from the Lochkov Formation.

The Silurian/Devonian boundary is predominantly developed in sedimentary strata of diverse slope topography. In historically the first GSSP erected globally (the Klonk section) 
the base of the Devonian is defined by the index graptolite U. uniformis uniformis (Figure 4). Traditionally, the most useful markers for the recognition of the Silurian/Devonian boundary are, besides graptolites, also conodonts, chitinozoans, trilobites or crinoids of the genus Scyphocrinites Zenker. The trilobites Tetinia minuta (Přibyl and Vaněk), and Warburgella rugulosa (Alth) were formerly used as additional markers to approximate the position of the Silurian/Devonian boundary in several sections around the Prague Synform [86]. Later, Carls et al. (2007) [58] identified the boundary more precisely based on the occurrence of Caudicriodus hesperius at the base of Bed 159 in the Požáry section.
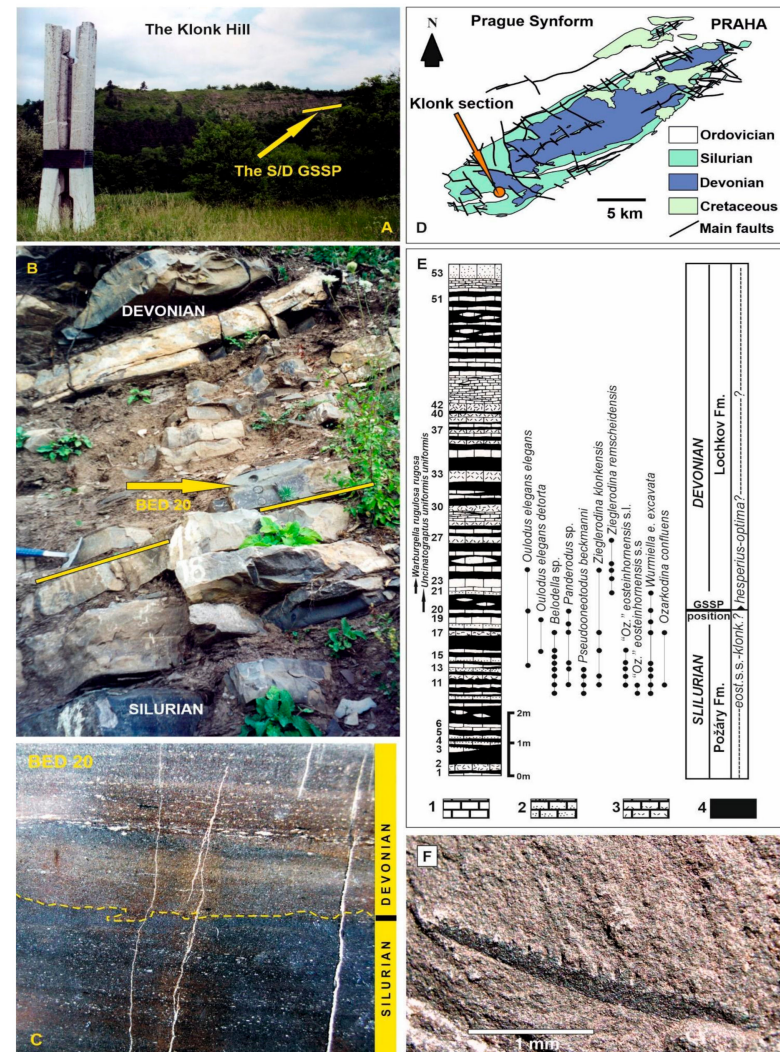

Figure 4. The Global Stratotype Section and Point (GSSP) for the base of the Devonian at Klonk Hill near Suchomasty. (A) - A view of the Klonk hill near Suchomasty. The yellow line marks the Silurian/Devonian boundary. (B) - A close-up view of the Silurian/Devonian boundary interval, the base of the Devonian begins in the upper part of Bed 20, as indicated by the yellow arrow. (C)—Bed 20, a polished section with marking of the boundary (yellow dotted line). (D) - A location of the GSSP of the Silurian/Devonian boundary at Klonk in simplified geological map of the central part of the Prague Synform. (E) - Conodont data from the Silurian-Devonian interval showing the position of the first occurrences of stratigraphically relevant taxa in relation to the GSSP. Data from $[57,87,88]$. Lithology: 1. Micritic and very fine-grained bioclastic limestones. 2. Medium-grained bioclastic limestones. 3. Coarse-grained, mostly crinoidal bioclastic limestones. 4. Calcareous mudstones up to shaly micrites. Abbreviations in biozonation: eost. s.s. = eosteinhornensis s.s., klonk. = klonkensis. (F) - The index graptolite, Uncinatograptus uniformis uniformis, the GSSP-defining taxon, from Bed 20, Klonk section.

Due to the fact that conodonts are abundant in carbonate successions of many different facies, they are, in some cases, the only faunal group that permits relatively precise recognition of the Silurian/Devonian boundary. Due to convenient facies development (limestones alternating with siltstones), the GSSP of the Silurian/Devonian boundary of the Prague Synform contains both the critical graptolites but also conodonts $[57,87,88]$. The late Silurian-Early Devonian conodont fauna is dominated by numerous genera primarily belonging to Spathognathodontidae and Icriodontidae, apart from a few representatives 
of Prioniodontidae. The conodonts of the boundary interval have been extensively studied $[2,13,21,57,58,78,87,89,90]$. Regional conodont zonation of the Lochkovian of the Prague Synform was developed by Slavík (2011) [91] and Slavík et al. (2012) [92]. The zonation for the latest Přídolí is more complicated, because Jeppsson (1988) [57] modified the first zonal concept of Walliser (1964) [2] and introduced a new zonation for the latest Přídolí based on conodonts from the GSSP section at Klonk. He refined the "single zonal scale" (i.e., the eosteinhornensis Zone) for the Přídolí Series and introduced the Ligonodina e. detorta Biozone (=Oulodus el. detortus). The application of the detortus Biozone was then used almost globally for the identification of the latest Přídolí (e.g., [10]), but it was problematic, as was revealed by Gouwy and Corradini (2006) [93], and then largely discussed by Carls et al. (2007) [58]. The first occurrence of the nominal taxon, Oul. el. detortus, occurs below the taxon osteinhornensis s.s., i.e., much deeper down in the Přídolí. Among the most important markers of the late Silurian in the Prague Synform are: Zieglerodina zellmeri and "Ozarkodina" eosteinhornensis s.l. (Walliser). The Devonian base is characterised by the first appearance of the earliest icriodontids-Caud. hesperius and Caud. woschmidti. Among spathognathodontids the most significant taxa are Z. petrea, Z. remscheidensis and "Oz." optima (Moskalenko) (see the summary in [21,94]). Zieglerodina petrea has a conspicuous gap in denticulation in P1 element near the cusp, similarly as taxa belonging to genus Cuspigrandiosa Murphy and Z. paucidentata (Murphy and Matti) (see discussion in [95]) and represents a promising "paucidentate" marker for the recognition of the Devonian base using the spathognathodontid clade [21]).

\subsection{Morocco}

Rocks across the Silurian/Devonian boundary were studied in two regions of Morocco: the Western Meseta and the Tafilalt.

In the Western Meseta, approximately located between the cities of Rabat, Marrakesh, Essauira and Taza, a sequence belonging to the southern Variscids is exposed, including rocks from the upper Silurian to the Carboniferous. For a summary of the geology of the area we refer to Becker and El Hassani (2020) [96]. In most of the region, the Přídolí is represented by graptolitic shales from where Charriére and Regnault (1989) [97] recorded $U$. u. uniformis, the basal Devonian index species, near the Douar Rouda village. Unfortunately, no conodonts were collected from the nodular limestones just above the graptolitic shales. More to the North-West, Benfrika et al. (2007) [98] studied a few sections of Přídolí to Middle Devonian age between Rabat and Tiflet, two of those spanning the Silurian/Devonian boundary. Silurian and Lochkovian are represented by thick sequences of black shales with intercalations of dark limestones. The boundary is placed with the graptolite index (e.g., [99]). Conodonts are very rare, and only two elements of Caud. woschmidti were documented above the first appearance of $U$. u. uniformis. Below the boundary, only a few elements of "Oz." eosteinhornensis s.l. are present, whereas the scarce association from the lowermost Lochkovian includes Zieglerodina remscheidensis, Belodella devonica (Stauffer) and Decoriconus fragilis (Branson and Mehl). Benfrika et al. (2007) [98] observed that $B$. devonica first occurs in levels with $U$. u. uniformis and suggested that it can be used as a regional index for the base of the Devonian.

In the Tafilalt region, located in southeastern Morocco, rocks from Ordovician to Carboniferous age are widely exposed. The Silurian and lowermost Devonian interval is represented by pelitic and marly sediments with interbedded limestone beds and lenses [100,101]. In the first approximation, they are represented by orthoceratid-rich limestones ("Orthoceras limestones") and by crinoidal limestones ("Scyphocrinites limestones"). The "Orthoceras limestones" occur from the Ludlow to the Lochkovian, whereas the "Scyphocrinites limestones" are documented across the Silurian/Devonian boundary, but their precise age has been disputed for a long time (e.g., [100-102]), until Corriga et al. (2014a, 2014b) [18,19] precisely defined the stratigraphical range of the two types of lobolithes and associated crinoidal crowns on the basis of a rich conodont fauna recovered from three sections South of Erfoud. The Authors demonstrated that the "Scyphocrinites limestones" occur across 
the Silurian/Devonian boundary and that the more primitive cirrus loboliths and genera Scyphocrinites and Carolicrinus are documented in the whole Přídolí, whereas the advanced plate loboliths and genera Camarocrinus and Marhoumacrinus are present in the topmost Přídolí beds and in the basal Lochkovian [19]. The conodont association across the boundary is rich and diversified [18] and enables the development of a precise biostratigraphical framework. The base of the Devonian is identified in all the three sections by the joint first occurrence of Caud. hesperius and Caud. woschmidti. Ozarkodina confluens (Branson and Mehl) is present up to the upper Přídolí, and Z. remscheidensis has its first occurrence between the $\mathrm{LO}$ of $\mathrm{Oz}$. confluens and the $\mathrm{FO}$ of icriodids. Oulodus el. detortus is limited to the Přídolí, whereas Oul. el. elegans enters in the Lochkovian. The genus Belodella, abundant in the Meseta, is not present.

\subsection{Spain}

The Silurian/Devonian boundary in Spain is present in several geological areas, i.e., the Eastern Iberian Chains (Cadenas Ibéricas Orientales), the Guadarrama spur of the Iberian Meseta, the Palentine Domain (Cantabrian Zone, NW Spain) and in the Spanish Central Pyrenees.

In the Eastern Iberian Chains, the boundary interval is represented by the Luesma Formation that comprises the uppermost Ludlow, Přídolí and part of the Gedinnian (=Lochkovian). The formation is $225 \mathrm{~m}$ thick and mostly consists of quarzites, shales and conglomerates. According to Carls (1977) [103] and Carls and Valenzuela-Ríos (2002) [104], the lowermost Gedinnian fauna $d 1 b \beta 2$ contains the earliest Devonian conodonts. In the Guadarrama area, the Silurian/Devonian boundary is developed in siliciclastic strata of the almost $900 \mathrm{~m}$ thick Alcolea Formation, where the boundary interval is formed by quartzites and sandstones. There, Fauna IV and Fauna V consist mostly of homalonotid trilobites and rhynchonellid and spiriferid brachiopods with correlation value, but no conodonts are reported [103]. In the Palentine Domain (NW Spain, Cantabrian Zone), the equivalent of the Luesma Fm. is the Carazo Formation, an up to $380 \mathrm{~m}$-thick sequence of sandstones, siltstones and shales. The upper member of the Carazo Fm. [105] contains silty and bioclastic limestones. These produced Silurian and Devonian conodonts in the Arauz section [106]. Predominantly carbonate successions prevail in several sections in the Spanish Central Pyrenees but only two sections provided conodonts: the Caballé 1 section with dark orthoceratid limestones $[107,108]$ and the Llesui section with dark-grey nodular limestones [109,110].

Among the most important additional markers for the Silurian/Devonian boundary interval in siliciclastic successions are the trilobite Acastella heberti (Gosselet) and the brachiopods Platyorthis ex gr. monnieri (Rouault) and Howelella mercurii (Gosselet) that co-occur together with Zieglerodina remscheidensis and Caud. woschmidti in the Eastern Iberian Chains. In the Palentine Domain, the Lower Devonian markers are the chitinozoans Urnochitina urna (Eisenack) and Eisenackitina bohemica (Eisenack), the trilobite Acastella cf. heberti, and the acanthodians Nostoloepis striata Pander and N. costata Goujet. These taxa occur above the Silurian/Devonian boundary (see [106]).

The conodont record from the Silurian/Devonian boundary is restricted to several sections in three geological areas. In the Eastern Iberian Chains, the section Cabezo del Pino contains the earliest Devonian taxon Caudicriodus woschmidti and Zieglerodina r. remscheidensis. In the Palentine Domain, the section Arauz provided the upper Silurian conodont fauna followed by typical earliest Devonian conodont markers: the oldest icriodontids—Caud. woschmidti, "Icr." angustoides ssp. and transitional forms Caud. woschmidti_- Icr." transiens. These are accompanied by spathognathodontids-Z. r. repetitor, Z. remscheidensis ssp. Z. The section comprises a complete succession from the uppermost Silurian to the lower Pragian with many described conodont, brachiopod, chitinozoan and vertebrate markers. The Pirenean Caballé 1 section provided Zieglerodina? cf. 40 (aff. remscheidensis) and Z. eladioi [107] that can be assigned either to the uppermost Přídolí or to the basal Lochkovian, and the Devonian marker Caud. woschmidti [108]. In the Llesui section, only late 
Silurian conodont taxa-Ozarkodina confluens, Oulodus e. elegans, O. cf. siluricus and O. e. detortus have been recorded $[109,110]$ and thus the Silurian/Devonian boundary cannot be precisely delimited. Another instructive Esera 3 section provided only nonconodont markers for the Silurian/Devonian boundary [111].

\subsection{Montagne Noire (South France)}

Although a precise location of the Montagne Noire in the Late Devonian is still debated, its position during the Early Palaeozoic along the northernmost margin of Gondwana or in the peri-Gondwana sector, somewhere between Laurussia and Gondwana, is generally agreed. Situated today at the southern margin of the French Central Massif, the Montagne Noire belongs to the external tectonic zone of the Variscan belt ([112] and references therein). A South-facing pile of low-grade to non-metamorphic rocks is there exposed, spanning the Precambrian to the early Carboniferous, and unconformably covered to the $S$ and SE by post-Variscan Carboniferous, Permian and Triassic rocks overlain in turn by Cenozoic deposits [113]. The Palaeozoic succession was affected by poliphased Hercynian deformation and syntectonic metamorphism; in contrast, the Alpine deformation was practically absent, resulting in good preservation of fossils and sedimentary fabrics.

Biostratigraphical studies on the Devonian and lower Carboniferous based on rich conodont associations have led to the definition of three boundary stratotypes: Givetian/Frasnian, Frasnian/Famennian and Devonian/Carboniferous. In contrast, conodont associations from Silurian and Lower Devonian carbonates are scarce and in strong need of a comprehensive taxonomic revision based on recent conodont biostratigraphy [113].

Two main stratigraphical situations may be recognised in the Montagne Noire: a nappe domain, best represented by the Pic-de-Bissous and Mont Peyroux areas, and the "écailles de Cabrières". The former documents the Devonian resting unconformably on the Lower Ordovician, whereas only in the latter a composite section has recorded in continuity an Upper Ordovician to Devonian sequence, including the recognition of the Silurian/Devonian boundary in marine Bohemian facies within a sandy limestone series yielding conodonts and chitinozoans [113-116].

In the Cabriéres area, the composite sequence of the "Plateau de Falgairas" derives from the integration of four complementary subprofiles (La Rouquette, La Chataignère, Col de l'Orte and Tiberet), each correlated with bio- and lithostratigraphical criteria [115]. The sequence starts with black pyritic mudstones, with intercalation of black shales, thin levels of grey limestone and black fossiliferous calcareous nodules, and continues with black shales with calcareous nodules, then thin, cephalopod-rich beds passing to brown silts and finally banded limestones with thin beds containing crinoid ossicles. Above, about $35 \mathrm{~m}$ of platy limestones with fossiliferous levels are exposed, followed by a few metres of quartzitic and dolomitic sandstones with iron oxide and cross-beddings [113]. Biostratigraphical data were provided on the basis of conodonts [115] and chitinozoans [117].

The upper part of the platy limestone yields orthocone nautiloids [118], brachiopods, trilobites, ostracods, bivalves and crinoids. Conodonts from this interval document the Oz. crispa and "Oz." eosteinhornensis s.l. zones [115]. Additionally, cephalopod-rich beds studied by Serventi and Feist (2009) [118] provided elements of Oul. el. detortus, thus documenting the upper Př́dolí eponymous zone. A bivalve association from the same beds confirms that age (Kř́ř́, pers. com.).

The quartzitic and dolomitic sandstones representing the upper part of the sequence are barren of conodonts. Poorly preserved casts of echinoderms and brachiopods are documented on bedding planes. According to brachiopods, the age is basal Devonian ("Gedinnian") [94]. Based on a personal communication by Havlíček in Feist (1985) [116], the brachiopod assemblage contains Glossinotoechia, Sicorhynchia, Iridistrophia, Strophonella, Cyrtina, Atrypa, Isorthis, Resserella, Parmothina and closely matches the characteristic fauna of the Bohemian Lochkovian.

Chitinozoans from the "plateau de Falgairas" were studied by De Boch (1982) [117], who documented 20 chitinozoan species belonging to eight genera, assigned to four assem- 
blages documenting the upper Ludlow, Přídolí and Lochkov. The assemblages IIIa and IIIb (Eisenackitina bohemica, Ancyrochitina cf. fragilis Eisenack, Ancyrochitina sp. and Ancyrochitina ex gr. "ancyrea") and IV (Angochitina devonica Eisenack, Angochitina sp., Ancyrochitina sp., Ancyrochitina ex gr. "ancyrea", Cingulochitina sp., Sphaerochitina sp. and Margachitina catenaria Obut) are attributed to the Lochkovian, with the assemblage IIIa possibly representing a transition zone between the Silurian and the Devonian [117].

In the Pic de Bissous area, a lowermost Devonian fauna attributed to "Spathognathodus steinhornensis remscheidensis" by Feist and Schönlaub (1974) [115], and likely representing various species of Zieglerodina, beside Z. remscheidensis, was documented. However, the basal Devonian index taxa Caud. woschmidti and Caud. hesperius are missing.

\subsection{Sardinia (Italy)}

The Sardinian basement is part of the South European Variscan chain [119] and exposes metamorphic rocks of Cambrian to early Carboniferous age. Different sequences are exposed in the southeastern and southwestern parts of the island: the Silurian and Lower Devonian parts recall the coeval sequences of Thuringia and Bohemia, respectively [120-124].

In SE Sardinia upper Silurian rocks are represented by a sequence of nodular limestone of Ludfordian to Přídolí age, informally named "Ockerkalk". A precise conodont stratigraphy of the unit was provided [124-130]. Above the "Ockerkalk", a pelitic unit named "Upper Graptolitic Shales" crops out. Graptolites are the only fossils abundant in the unit, and document three graptolite zones of the Lochkovian. No section exposes the Silurian/Devonian boundary, which likely lies at the formation transition.

Silurian and lowermost Devonian rocks of SW Sardinia are among the most studied sediments of the whole Palaeozoic sequence of the island, due to the rich fossiliferous content. However, despite the richness and the good preservation of the fossil remains, outcrops are, in general, strongly tectonised and often constituted by a group of scattered blocks exposed here and there, without any undisturbed sections [123,131-134]. The latest Silurian and/or earliest Devonian conodonts are documented from various localities (e.g., $[135,136])$, but the boundary is exposed only in the Mason Porcus section $[130,137,138]$.

A conodont zonal scheme for the Silurian was prepared by Corradini and Serpagli $(1998,1999)[5,139]$; the upper part of it was later updated by Corradini and Corriga (2012) [11] in their Přídolí-Lochkovian zonation. Additionally, Corriga et al. (2009) [140] provided a summary of Silurian conodont occurrences in the Silurian of Sardinia.

Due to the scarcity of sections exposing the Silurian/Devonian limit it is difficult to provide a detailed series of events along the boundary beds. Combining data from the Mason Porcus section [130] and various other outcrops, it is possible to state that Ozarkodina confluens has its last occurrence in the latest Silurian beds, just below the first appearance of Zieglerodina remscheidensis. The FO of Caud. hesperius marks the base of the Devonian, whereas Caud. woschmidti enters just above.

\subsection{Carnic Alps (Austria and Italy)}

In the Carnic Alps, located across the Italian-Austrian border, one of the best exposed and complete Palaeozoic successions in the world, ranging from the Middle Ordovician to the late Permian, is exposed. Rocks from the Middle Ordovician to the earliest Pennsylvanian age belong to the pre-Variscan sequence and represent one of the better preserved and most studied sequences for this interval. For a recent overview of the pre-Variscan sequence, refer to [20,141,142].

In the Carnic Alps, sediments across the Silurian/Devonian boundary are exposed in various depositional settings from very shallow water to basin [17]. Four main lithofacies, representing different depths of deposition and hydrodynamic conditions, have been described [143-145]. The Wolayer-facies is characterised by proximal sediments and the Bischofalm-facies by deep water euxinic deposits; the Plöcken-facies and the Findenigfacies are intermediate between the former. In rough approximation, the four facies seem to replace each other from North-West to South-East in the western and central sectors of 
the Carnic Alps, whereas in the western sector the sequence recalls an intermediate feature between the Wolayer and the Plöcken facies [146,147].

The lithostratigraphy of the pre-Variscan sequence has been recently formalised [148] and thirty-six formations were discriminated. Four units span the Silurian/Devonian boundary (Alticola Fm., Seekopf Fm., Nölbling Fm. and Bischofalm Fm.), whereas the Rauchkofel Fm. starts at the very base of the Lochkovian. The Alticola Fm. [149] consists of a well bedded cephalopod wackestone to packstone of Ludlow-earliest Lochkovian age; the Silurian/Devonian boundary lies in the uppermost part of the unit, very close to its top. The Seekopf Fm. [150] consists of a grayish very shallow water lithoclastic limestone with abundant fossil debris of Př́dolí-early Pragian age. The Nölbling Fm. [151] is made of black graptolitic shales with interbedded layers and nodules of a dark cephalopod wackestone to mudstone; its age spans the early Silurian through the end of the Lochkovian. The Bischofalm Fm. [152] consists of black pelites and alum shales of Llandovery to Lochkovian age. The lower part of the Rauchkofel Fm. [153] is represented by a mainly laminated dark grey well-bedded platy mudstone to wackestone with intercalations of black shales and marls, and locally calcarenites.

The conodont stratigraphy of several sections exposing rocks across the Silurian/ Devonian boundary was studied in great detail in, from East to West, Rifugio Lambertenghi Fontana III [77], Seewarte [17,154], Rauchkofel Boden [20,144], Valentintörl [95], Cellon [2,12,155], Freikofel South II [17], Oberbuchach II [156,157], Oberbuchach Ib [158,159], Rio Malinfier West [160] and Monte Cocco II [161]. Based on conodont faunas from most of these sections and other scattered data, Corradini and Corriga (2012) [11] proposed a conodont zonation scheme for the Přídolí and the Lochkovian.

Corradini et al. (2020) [17] studied in detail the conodont distribution across the Silurian/Devonian boundary in the Carnic Alps, and recognised a calendar of events (First Occurrences and Last Occurrences) just below or above the boundary. In the latest Silurian the last occurrence of Ozarkodina confluens is registered, just followed by the LO of Wurmiella alternata Corradini and Corriga, and by first occurrences of Zieglerodina remscheidensis and Z. eladioi. The latest Silurian events are the LO of Zieglerodina zellmeri and Zieglerodina klonkensis, just below the FO of Caud. hesperius; that is, the conodont index taxon for approximating the base of the Devonian. Caudicriodus woschmidti enters at the same level, whereas Zieglerodina schoenlaubi just above. Various species of Zieglerodina (Z. formosa, Z. mashkovae and Z. petrea) and a species of Cuspigrandiosa (Cuspigrandiosa sp. K Corriga et al.) have their First Occurrence within the lowermost Lochkovian Caud. hesperius Zone. Recent unpublished data from newly studied sections confirm this list of events.

\subsection{Graz Palaeozoic and Burgenland (South-East Austria)}

Beside the Carnic Alps, latest Silurian and basal Devonian conodonts were documented in a few other localities in southeastern Austria; more precisely, South of Graz and in the South Burgenland.

The Graz Palaeozoic exposes rocks from Silurian to Carboniferous age. For a summary of the stratigraphy refer to Hubmann and Gross (2015) [162]. The Silurian part of the sequence is dominated by alkaline mafic lavas and pyroclastics, succeded by progressive carbonate production during the late Silurian and Devonian [163]. Conodonts across the Silurian/Devonian boundary were documented by Ebner $(1976,1994)$ [164,165] from the Eggenfeld section: data are very scarce, but the occurrence of "Oz." eosteinhornensis s.1. indicates a Přídolí age for a 2.40 m-thick interval of dark bedded dolostones. Above, after about $1 \mathrm{~m}$ of tuffitic shales, a few elements of Caud. hesperius were documented from a $20 \mathrm{~cm}$ dolomitic level.

In the Bungenland, poorly preserved conodonts were documented from the "Baron von Kottwitz" quarry, near the Austrian-Hungarian boundary. Suttner and Lukeneder (2004) [166] collected two P1 elements of Oz. confluens from a two-meter-thick interval with beds consisting almost exclusively by serpulid tubes. Above, the sequence continues with a tectonically stressed unit of dolomites, shale and siltstone a few metres thick. From 
the lower part of that Suttner (2009) [167] collected a basal Lochkovian fauna, with Caud. woschmidti, "Oz." eosteinhornensis s.l., Zieglerodina remscheidensis and possibly other species of Zieglerodina, and rare conodont elements.

\subsection{Balkans}

In the Balcan region, conodonts around the Silurian/Devonian boundary are well documented only in Albania and Bulgaria.

Information on the Silurian/Devonian boundary in Albania is scarce and limited to a few outcrops in the "Korabi Zone", in the northeastern part of the country, where the rock sequence is strongly faulted and metamorphosed and consists of various clastic and carbonate rock with intercalations of mostly acid volcanics [168]. Silurian rocks are mainly represented by graptolitic shales, whereas limestones are dominant in the Devonian. However, fossils are extremely rare except graptolites of Silurian age and rare dacryoconarids in the Devonian. A few poorly preserved conodonts were documented by Schönlaub and Meco (1986) [168] and Meco (2010) [169]. Ozarkodina confluens and "Oz." eosteinhornensis s.1. were collected from the upper Přídolí, whereas Caud. woschmidti and Z. cf. remscheidensis were recovered from the lower Lochkovian.

In Bulgaria, the sedimentary strata of the boundary interval occur in the western part of the country in three Alpine tectonic structural units: the West Balkan Unit, the Lyubash Monocline and the Morava Unit. Stratigraphically, the most important is the Gorna Vrabcha 2 section in the Morava Unit because of the presence of carbonates. The upper Silurian and Lower Devonian carbonate-siliciclastic rocks are preserved as isolated and tectonically disturbed outcrops with shale-limestone alternation and nodular limestones in the Přídolí and Lochkovian. These rocks belong to the 185 m-thick Vrabcha Formation of Spassov (1973) [170]. The Silurian/Devonian boundary in the Gorna Vrabcha 2 section was studied for conodonts [170-174] and for graptolites [175].

In general, the most important additional markers of the boundary in West Bulgaria are graptolites. These are present mostly in the siliciclastic strata of the Balkan and Lyubash Unit and belong to the Přídolí ultimus-parultimus and branickensis-lochkovensis zones, and Lochkovian uniformis and hercynicus (see [174]). The index graptolite U. u. uniformis is, however, missing in the Morava Unit, where the best markers for the base of the Devonian are conodonts. Additionally, the lower Lochkovian in the Balkan Unit can be approximated by the dacryoconarid tentaculite Homoctenowakia bohemica (Bouček) [176].

The stratigraphy of the siliciclastic-carbonate member (the Morava Unit) is based on conodont data. The Ludfordian to Lochkovian interval in the Gorna Vrabcha Section 2 indicates the siluricus, eosteinhornensis and woschmidti zones [175]. The uppermost Silurian is characterised by Wurmiella excavata (Branson and Mehl) and "Ozarkodina" eosteinhornensis s.l. The first occurrence of Caud. woschmidti (Ziegler) defines approximately the base of the Devonian. According to Boncheva et al. (2007) [174], the lower Lochkovian taxa include also Zieglerodina remscheidensis, "Icr." postwoschmidti Mashkova, "Icr." rectangularis Carls and Gandl and some coniform taxa (Belodella, Panderodus, Pseudooneotodus).

\subsection{Turkey}

The complicated stratigraphy and tectonics of Turkey make any attempt to generalise a global description of the region difficult. The actual configuration of Turkey results from the amalgamation of numerous and separate terranes. The Devonian is there mainly documented in the Pontides, Taurides and Arabian Plate, with the former having an Avalonian affinity and the latter two a clear Gondwana one [177]. Some of these areas expose successions documenting the Silurian/Devonian limit; some others reveal strong unconformities at the period boundary. However, even in continuous sections, the Silurian/Devonian boundary is only tentatively assigned within a large stratigraphic interval.

The Arabian Plate exposes a sequence in southeastern Anatolia where the Silurian/ Devonian boundary is provisionally located in the uppermost part of the Dadaş Formation, a restricted inner-shelf unit evolving to a tidal flat in the upper part [178]. The Dadaş 
Formation unconformably covers the Middle-Upper Ordovician and is represented by basal dark organic-rich shales with interbedded limestones and sandstones, passing to summital sandstones, marls and calcareous siltstones. The faunal association has documented palinomorphs, brachiopods, bryozoans, graptolites, conodonts, crinoids, corals and ostracods assigned to the late Silurian-Early Devonian. Unluckily, the conodont marker for the boundary Caud. woschmidti is not present [179], and precise data on the occurrence of other taxa that may help to place the boundary are not available.

The Devonian exposed in the Taurides appears mostly in continuity with the Silurian and a complete Devonian sequence documents a transition between an inter- to supratidal shallow facies to a deep shelf at the end of the period [177,180]. However, the boundary is not precisely placed. The Taurides derive from the assemblage of numerous tectono-stratigraphic units, among which the autochthonous Geyikdağ 1 Unit documents a rich Palaeozoic sequence of carbonate and siliciclastic sediments of terrestrial to deep water environment [181]. The Silurian/Devonian in the Saimbeyli-Tufanbeyli area (Eastern Taurides) is recorded at the passage between the upper part of the Yukari Yayla Formation, represented by shales, sandstones, siltstones and limestone with Orthoceras and the Ay1 Tepesi Formation, constituted by shales, sandstones, micritic limestones and sandstones ([181]). The Yukari Yayla Formation had been attributed to the latest Landovery to earliest Wenlock and post-middle Ludlow by Göncüoğlu et al. (2004) [182], who regarded the Lower Devonian deposited over an unconformity. However, in sample CON-11, collected in the uppermost part of the "Orthoceras limestone" interval, the Authors collected Zieglerodina eladioi (Valenzuela Rios): the species is documented from the latest Prrídolí to the middle Lochkovian [183]; therefore, the Silurian/Devonian boundary should occur in the uppermost part of the "Orthoceras limestone" unit or in the lowermost part of the overlying dark siltstones and shales. Unfortunately, no other biostratigraphical data are available.

In the central Taurides, Göncüoğlu and Kozur (2000) [184] studied four conodont samples in the upper part of the Ovacik section, where some metres of limestone are exposed. The lower sample, collected at the base of the limestones just above a transition from siltstones, yielded Caud. woschmidti, Z. remscheidensis, Zieglerodina sp., Pseudooneotodus beckmanni (Bischoff and Sannemann) and Panderodus unicostatus (Branson and Mehl), indicating a lowermost Lochkovian age. No data are available from older strata, and slightly above, a middle Lochkovian fauna is reported.

Several microterranes are included in the Pontides. The Ordovician-Lower Devonian exposed in the Çamdağ area (Zonguldak Terrane) documents the most complete successions and includes the Silurian-Lower Devonian Findıklı Formation [185]. The lower part of the Findıklı Formation is represented by a siliciclastic unit with intercalated graptolitic black shales referred to the Silurian by acritarchs and graptolites [186], followed by "Orthoceras" limestones with fragmentary conodonts possibly of late Silurian (Přídolí) age [187]. Boncheva et al. (2009) [188] collected a poorly preserved Silurian and Lower Devonian fauna from the Kalabak Dere section. The authors tentatively located the Silurian/Devonian boundary in a $25 \mathrm{~m}$ interval between samples 130-B and 130-C. They reported "Oz." eosteinhornensis, and Oul. el. detortus from samples 130-B, and fragments of Caud. woschmidti from sample 130-C. However, the state of preservation of figured elements makes precise taxonomic determinations very difficult.

\section{The Silurian/Devonian Boundary in More Distant Areas of Gondwana}

Beside the North Gondwana terranes that faced the Rheic ocean, in the other areas of North Gondwana detailed data on conodonts across the Silurian/Devonian boundary are documented only from Argentina and Australia.

\subsection{Argentina}

Argentina was part of southwest Gondwana, and at the Silurian/Devonian boundary was located at high southern latitudes. Upper Silurian and lowermost Devonian conodonts were documented [189-191] from the Los Espejos Formation of the San Juan 
Precordillera. The unit is represented by marine siliciclastic rocks, mainly shale, sandstone and siltstone [192,193], and is interpreted as deposited on storm-dominated clastic shelf from offshore to shoreface settings [194,195]. The lower part of the Los Espejos Formation is predominantly composed of reddish and greenish phosphate-rich bioturbated mudstone and shale. In the middle part, the shaly succession includes thin sandstone beds bearing a shelly fauna and abundant trace fossils of the Cruziana Ichnofacies [196]. This shelly fauna is composed of abundant brachiopods belonging to the genera Harringtonina, Clarkeia, and Australina, among others, associated with trilobites, nautiloids, ostracods and crinoids. The upper part of the formation is characterised by a fossiliferous burrowed mudstone interbedded with a coquinoid sandstone. Latest Silurian and basal Devonian conodonts were reported from coquinoid beds and lenses in the Ancha creek and Poblete sections. A precise biostratigraphical assignment is difficult due to the abundance of reworked material. The late Přídolí fauna is dominated by the endemic species Ozarkodina huenickeni Gómez et al. and includes "Oz." eosteinhornensis s.l., "Oz." eosteinhornensis s.s., Oulodus el. elegans, Wurmiella excavata and some coniform species (Dapsilodus obliquicostatus (Branson and Mehl), Panderodus unicostatus, Pseudooneotodus beckmanni, Ps. bicornis bicornis Drygant, Ps. bic. contiguus Corradini). The Lochkovian is discriminated in the upper part of the Poblete section thanks to the presence of Caud. cf. hesperius. The association includes Oz. huenickeni, W. excavata, Ps. beckmanni, Pand. unicostatus and Zieglerodina sp.

\subsection{Australia}

In the latest Silurian and Early Devonian, Australia was located in eastern Gondwana at tropical latitudes. Silurian and Devonian conodonts were documented in several papers dealing with different areas (for a summary see Simpson, 1995 [197]). The basal Devonian index Caud. woschmidti is widely documented, but a sequence across the Silurian/Devonian boundary is exposed only in a few localities (e.g., [198,199]). Farrell (2003, 2004) $[199,200]$ studied the sequence in central western New South Wales, and detected the Silurian/Devonian boundary within the Camelford limestone, a massive limestone almost $400 \mathrm{~m}$ thick with intercalation of argillaceous and conglomeratic intervals. The conodont fauna is dominated by coniforms (mainly Panderodus and Belodella), whereas ozakodinids (Zieglerodina sp., W. excavata and Ozarkodina sp.) and Oul. el. detortus are rare and show irregular occurrences. The base of the Devonian is indicated by the first occurrence of Caud. hesperius.

At Broken River Crossing, in Northeast Queensland, Simpson (2000) [198] described three sections from the upper member of the Jack Limestone, a thickly bedded and massive limestone with crinoid stems, bryozoans, brachiopods and stromatoporoids. In the uppermost part of the unit the Author collected icriodids that he attributed to Caud. hesperius, togheter with ozarkodinids referable to Zieglerodina sp. However, Barrick et al. (2021) [201] moved the icriodids figured by Simpson to a new species of the genus Praeicriodus, specifically Pr. simpsoni Barrick et al., and claimed a latest Silurian age for these levels.

\section{The Silurian/Devonian Boundary on the Northern Side of the Rheic Ocean}

North of the Rheic suture upper Silurian and lowermost Devonian rocks are mainly represented by siliciclastics, shallow-marine and/or continental deposits (e.g., [202,203]), indicating depositional environments not suitable for the presence of conodonts. When data on conodonts are missing, the stratigraphy is mainly based on chitinozoans for shallow marine rocks. In Great Britain the Silurian/Devonian boundary is represented by nonmarine rocks and any consideration on the boundary is a speculation [204]. In other areas, a hiatus is present across the Silurian/Devonian boundary.

A few conodont data are available only from Podolia and Baltica. 


\subsection{Podolia}

Podolia is an historical region now mainly located in western Ukraine. Uppermost Silurian and Lower Devonian conodonts have been widely investigated for many years (e.g., [205-210]). Drygant and Szaniawski (2012) [211] studied in detail several sections of the Dniester River basin and compared new data with old collections, resulting in a regional zonation for the latest Přídolí to the early Pragian time frame. In the Silurian the Authors discriminated the "Oz." eosteinhornensis s.1. Zone, whereas the Caud. hesperius Zone included all the lower Lochkovian. The first occurrence of Caud. hesperius was used to identify the Silurian/Devonian boundary, whereas Caud. woschmidti enters slightly higher. A few taxa have their first or last occurrence approximately at the boundary level: Ozarkodina confluens, "Oz." eosteinhornensis s.l. and Oul. el. detortus are limited to the Přídolí, whereas Zieglerodina remscheidensis, Z. formosa and Decoriconus fragilis enters at the very base of the Lochkovian. Additionally, Zieglerodina klonkensis is reported only from the uppermost Silurian beds.

\subsection{Baltic Area}

In the Baltic area (Gotland, Estonia, Lithuania) a hiatus is present between the Silurian and the Lower Devonian (e.g., [212-214]) and up to the complete Prrídolí is often missing. Therefore, the Silurian/Devonian boundary is not documented. Late Přídolí conodonts are documented only from a few localities, as the Milaiciai 103 borehole from where Spiridonov et al. (2020) [75] discriminated a Z. remscheidensis Zone in the upper part of the Oul. el. detortus Zone. Ozarkodina confluens shortly occurs with Z. remscheidensis, whereas Oul. el. detortus and "Oz." eosteinhornensis s.l. disappear in the upper part of the zone. A few species are still present in the uppermost limestone sample (Oz. ambigua Viira, Oul. el. elegans and Z. remscheidensis), where Zieglerodina inordinata (Viira) has its only occurrence. Above, a sharp transition to siliciclastics prevents any younger conodont datum.

\section{Discussion and Conclusions}

Conodont whose first appearance datum (FAD) best approximates the base of the Devonian System is Caudicriodus hesperius. Other taxa have their first or last appearances close to the first appearance of Caud. hesperius, and can be useful to reach a relatively precise allocation of the Silurian/Devonian boundary (Figure 5):

- Ozarkodina confluens is in general limited to the Silurian, and has its last occurrence in the uppermost Přídolí strata, but in Bohemia it occurs also just above the boundary.

- Zieglerodina remscheidensis enters in the latest Silurian beds, just above the LO of Oz. confluens, in the Carnic Alps, Sardina and Morocco, whereas elsewhere is documented close to the base of the Devonian, together with Caud. hesperius.

- Zieglerodina klonkensis is the marker of the last Silurian zone in the regional zonation for Bohemia, where its range ends just slightly above the boundary. The species rarely occurs in the latest Silurian of the Carnic Alps and Podolia, and a single specimen is documented from the lowermost Lochkovian of Sardinia.

- Caudicriodus woschmidti is a Devonian species. Its first occurrence is often accompanied by the FO of Caud. hesperius, whereas at place (i.e., Bohemia) C. woschmidti occurs in a slightly younger bed.

- $\quad$ Oulodus elegans detortus has been considered a good marker for the upper Přídolí for a long time. However, it ranges in most of the Přídolí and in the lowermost Lochkovian; therefore, its utility for recognising the position of the boundary is limited. 


\begin{tabular}{|c|c|c|c|c|c|c|c|c|c|}
\hline $\begin{array}{l}\text { Age } \\
\text { (Ma) }\end{array}$ & PERIOD & & OCHIAge & $\begin{array}{l}\text { CONODONT } \\
\text { ZONATION }\end{array}$ & Bohemia & $\begin{array}{l}\text { Carnic } \\
\text { Alps } \\
\text { A(4)(5)(6) }\end{array}$ & $\underset{(4)(5)(6)}{\text { Sardinia }}$ & $\begin{array}{r}\text { Morocco } \\
(4)(5)(6)\end{array}$ & $\underset{\text { Spain }}{\text { Spa }}$ \\
\hline 418 寻 & DEVONIAN & $\begin{array}{l}\vec{y} \\
\frac{a r}{\sqrt{u}} \\
\end{array}$ & $\begin{array}{l}\text { Lochkovian } \\
419.0\end{array}$ & Caudicriodus hesperius & $\downarrow$ & & $\perp$ & & $\perp \perp$ \\
\hline 420 寻 & SILURIAN & $\begin{array}{l}\bar{a} \\
\frac{0}{a} \\
\frac{0}{2}\end{array}$ & & $\begin{array}{c}\text { Upper Oul. el. detortus/ } \\
\text { Z. klonkensis }\end{array}$ & & 1 & 1 & 1 & 11 \\
\hline
\end{tabular}

Figure 5. Correlation between conodont markers across the Silurian/Devonian boundary in the investigated areas. 1: Ozarkodina confluens; 2: Oulodus elegans detortus; 3: Zieglerodina klonkensis; 4: Zieglerodina remscheidensis; 5: Caudicriodus hesperius; 6: Caudicriodus woschmidti.

Aside from these species that widely occur in peri-Gondwana terranes and elsewhere, a few others show good potential for correlation of the uppermost Silurian and lowermost Devonian beds, but up to now are documented only locally or in a few areas, or are very rare. Among these, Z. eladioi, Z. petrae and Z. schoenlaubi should be mentioned.

It is noteworthy to mention that the earliest icriodontids which represent the most reliable markers for the Silurian/Devonian boundary recognition are facies-limited and thus not represented or rare in most pelagic environments. According to our analyses, ozarkodinids are less sensitive to water depth; thus, they may have a more universal dispersal in oceanic waters. Therefore, an agreement on such a universal boundary marker of the spathognathodontid clade could be the future direction of our research.

Author Contributions: Conceptualization: A.F., C.C., data analysis, A.F., C.C., M.G.C., L.S.; writingoriginal draft preparation, A.F., C.C., M.G.C., L.S.; writing-review and editing, A.F., C.C., M.G.C., L.S. All authors have read and agreed to the published version of the manuscript.

Funding: This research was supported by the Czech Science Foundation project GA 21-21829S (to Ladislav Slavík) and the Research Plan of the Institute of Geology of the Czech Academy of Sciences (RVO67985831). This paper is a contribution to IGCP Project n. 652 "Reading time in Paleozoic sedimentary rocks".

Institutional Review Board Statement: Not applicable.

Informed Consent Statement: Not applicable.

Data Availability Statement: The presented data are available on request from the corresponding Author.

Acknowledgments: The Authors kindly acknowledge the Assistant Editor for the invitation to contribute to the journal and for the skilled editorial guidance during manuscript preparation. Suggestions provided by the four anonymous Reviewers are acknowledged.

Conflicts of Interest: The authors declare no conflict of interest.

\section{References}

1. Negri, A.; Ferretti, A.; Wagner, T.; Meyers, P.A. Organic-carbon-rich sediments through the Phanerozoic: Processes, progress, and perspectives. Palaeogeogr. Palaeoclimatol. Palaeoecol. 2009, 273, 213-217. [CrossRef]

2. Walliser, O.H. Conodonten des Silurs. Abh. Hess. Landesamt. Bodenforsch. 1964, 41, 1-106.

3. Aldridge, R.J.; Schönlaub, H.P. Conodonts. In A Global Standard for the Silurian System; Geological Series; Holland, C.H., Bassett, M.G., Eds.; National Museum of Wales: Cardiff, UK, 1989; Volume 9, pp. 274-279.

4. Koren, T.N.; Lenz, A.C.; Loydell, D.K.; Melchin, M.J.; Storch, P.; Teller, L. Generalized graptolite zonal sequence defining Silurian time intervals for global paleogeographic studies. Lethaia 1996, 29, 59-60. [CrossRef]

5. Corradini, C.; Serpagli, E. A Silurian conodont zonation from late Llandovery to end Přídolí in Sardinia. Boll. Soc. Paleont. Ital. 1999, 38, 255-273.

6. Melchin, M.J.; Cooper, R.A.; Sadler, P.M. The Silurian Period. In A Geologic Time Scale 2004; Gradstein, F.M., Ogg, J.G., Smith, A.G., Eds.; Cambridge University Press: Cambridge, UK, 2004; pp. 188-201.

7. Melchin, M.J.; Sadler, P.M.; Cramer, B. Chapter 21-The Silurian Period. In The Geologic Time Scale 2020; Gradstein, F.M., Ogg, J.G., Schmitz, M.D., Ogg, G.M., Eds.; Elsevier: Boston, MA, USA, 2020; Volume 2, pp. 695-732. 
8. Jeppsson, L.; Eriksson, M.E.; Calner, M. A latest Llandovery to latest Ludlow high resolution biostratigraphy based on the Silurian of Gotland-A summary. GFF 2006, 128, 109-114. [CrossRef]

9. Sadler, P.M.; Cooper, R.A.; Melchin, M. High-resolution, early Paleozoic (Ordovician-Silurian) time scales. Bull. Geol. Soc. Am. 2009, 121, 887-906. [CrossRef]

10. Cramer, B.D.; Brett, C.E.; Melchin, M.J.; Männik, P.; Kleffner, M.A.; McLaughlin, P.I.; Loydell, D.K.; Munnecke, A.; Jeppsson, L.; Corradini, C.; et al. Revised correlation of Silurian Provincial series of North America with global and regional chronostratigraphic units and $\delta^{13} C_{\text {carb }}$ chemostratigraphy. Lethaia 2011, 44, 185-202. [CrossRef]

11. Corradini, C.; Corriga, M.G. A Přídolí-Lochkovian conodont zonation in Sardinia and the Carnic Alps: Implications for a global zonation scheme. Bull. Geosci. 2012, 87, 635-650. [CrossRef]

12. Corradini, C.; Corriga, M.G.; Männik, P.; Schönlaub, H.P. Revised conodont stratigraphy of the Cellon section (Silurian, Carnic Alps). Lethaia 2015, 48, 56-71. [CrossRef]

13. Vacek, F.; Slavík, L.; Sobień, K.; Cáp, P. Refining the late Silurian sea-level history of the Prague Syncline-A case study based on the Přídolí GSSP (Czech Republic). Facies 2018, 64, 30. [CrossRef]

14. Rong, J.; Wang, Y.; Zhan, R.; Fan, J.; Huang, B.; Tang, P.; Li, Y.; Zhang, X.; Wu, R.; Wang, G.; et al. Silurian integrative stratigraphy and timescale of China. Sci. China Earth Sci. 2019, 62, 89-111. [CrossRef]

15. Becker, R.T.; Marshall, J.E.A.; Da Silva, A.-C. Chapter 22-The Devonian Period. In The Geologic Time Scale 2020; Gradstein, F.M., Ogg, J.G., Schmitz, M.D., Ogg, G.M., Eds.; Elsevier: Boston, MA, USA, 2020; Volume 2, pp. 733-810.

16. Martinsson, A. The Silurian-Devonian boundary: Final report of the Committee of the Siluro-Devonian Boundary within IUGS Commission on Stratigraphy and a state of the art report for Project Ecostratigraphy. IUGS Ser. A 1977, 5, 347.

17. Corradini, C.; Corriga, M.G.; Pondrelli, M.; Suttner, T.J. Conodonts across the Silurian/Devonian boundary in the Carnic Alps (Austria and Italy). Palaeogeogr. Palaeoclimatol. Palaeoecol. 2020, 549, 109097. [CrossRef]

18. Corriga, M.G.; Corradini, C.; Walliser, O.H. Upper Silurian and Lower Devonian conodonts from Tafilalt, southeastern Morocco. Bull. Geosci. 2014, 89, 183-200. [CrossRef]

19. Corriga, M.G.; Corradini, C.; Haude, R.; Walliser, O.H. Conodont and crinoid stratigraphy of the upper Silurian and Lower Devonian scyphocrinoid beds of Tafilalt, southeastern Morocco. GFF 2014, 136, 65-69. [CrossRef]

20. Schönlaub, H.P.; Corradini, C.; Corriga, M.G.; Ferretti, A. Chrono-, litho- and conodont bio-stratigraphy of the Rauchkofel Boden Section (Upper Ordovician-Lower Devonian), Carnic Alps, Austria. Newsl. Stratigr. 2017, 50, 445-469. [CrossRef]

21. Hušková, A.; Slavík, L. In search of Silurian/Devonian boundary conodont markers in carbonate environments of the Prague Synform (Czech Republic). Palaeogeogr. Palaeoclimatol. Palaeoecol. 2020, 549, 109126. [CrossRef]

22. Heckel, P.H.; Witzke, B.J. The Devonian System, Devonian world paleogeography determined from distribution of carbonates and related lithic palaeoclimatic indicators. In Palaeontology; House M., R., Scrutton C., T., Bassett M., G., Eds.; Palaeontological Association: London, UK, 1979; Volume 23, pp. 99-123.

23. Cocks, L.R.M.; Fortey, R.A. Faunal evidence for oceanic separations in the Palaeozoic of Britain. J. Geol. Soc. Lond. 1982, 139, 465-478. [CrossRef]

24. Boucot, A.J.; Gray, J. A Palaeozoic Pangea. Science 1983, 222, 571-581.

25. Fortey, R.A.; Cocks, L.R. Arenig to Llandovery faunal distributions in the Caledonides. In The Caledonian-Appalachian Orogen; Harris, A.L., Fettes, D.J., Eds.; Geological Society, London, Special Publications: London, UK, 1988 ; Volume 38, pp. $233-246$.

26. Fortey, R.A.; Cocks, L.R.M. Palaeontological evidence bearing on global Ordovician-Silurian continental reconstructions. Earth Sci. Rev. 2003, 61, 245-307. [CrossRef]

27. Paris, F.; Robardet, M. Early Palaeozoic palaeobiogeography of the Variscan regions. Tectonophysics 1990, 177, 193-213. [CrossRef]

28. Cocks, L.R.M.; Torsvik, T.H. Earth geography from 500 to 400 million years ago: A faunal and palaeomagnetic review. J. Geol. Soc. Lond. 2002, 159, 63-644. [CrossRef]

29. Cocks, L.R.M.; Torsvik, T.H. European geography in a global context from the Vendian to the end of the Palaeozoic. In European Lithosphere Dynamics; Gee, D.G., Stephenson, R.A., Eds.; Geological Society of London: London, UK, 2006 ; Volume 32, pp. 83-95.

30. Robardet, M. The Armorica "microplate": Fact or fiction? Critical review of the concept and contradictory palaeobiogeographical data. Palaeogeogr. Palaeoclimatol. Palaeoecol. 2003, 195, 125-148. [CrossRef]

31. Smith, A.G.; Briden, J.C.; Drewry, G.E. Phanerozoic world maps. In Organisms and Continents through Time; Hughes, N.F., Ed.; The Palaeontological Association: London, UK, 1973; Volume 12, pp. 241-269.

32. Smith, A.G.; Hurley, A.M.; Briden, J.C. Phanerozoic Palaeocontinental World Maps; Cambridge University Press: Cambridge, UK, $1981 ;$ p. 102.

33. Morel, P.; Irving, E. Tentative palaeocontinental maps for the early Phanerozoic and Proterozoic. J. Geol. 1978, 86, 536-561. [CrossRef]

34. Scotese, C.R.; Bambach, R.K.; Barton, C.; Van der Voo, R.; Ziegler, A.M. Paleozoic base maps. J. Geol. 1979, 87, 217-277. [CrossRef]

35. Scotese, C.R.; Van der Voo, R.; Barrett, S.F. Silurian and Devonian base maps. In Evolution and Environment in the Late Silurian and Early Devonian; Chaloner, W.G., Lawson, J.D., Eds.; Royal Society: London, UK, 1985; Volume 309, pp. 57-77.

36. Van der Voo, R. Palaeozoic assembly of Pangea: A new plate tectonic model for the Taconic, Caledonian and Hercynian orogenies. Trans. Am. Geographys. Union 1979, 60, 241.

37. Van der Voo, R. Pre-Mesozoic palaeomagnetism and plate-tectonics. Annu. Rev. Earth Planet. Sci. 1982, 10, 191-220. 
38. Van der Voo, R. Palaeozoic palaeogeography of North America, Gondwana and intervening displaced terranes: Comparisons of palaeomagnetism with palaeoclimatology and biogeographical patterns. Bull. Geol. Soc. Am. 1988, 100, 311-324. [CrossRef]

39. Livermore, R.A.; Smith, A.G.; Briden, J.C. Palaeomagnetic Constraints on the Distribution of Continents in the Late Silurian and Early Devonian. Philos. Trans. R. Soc. London. Ser. B Biol. Sci. 1985, Volume 309, $29-56$.

40. Perroud, H. Synthèse des résultats paléomagnétiques sur le Massif Armoricain. Hercynica 1985, 1, 65-71.

41. Tait, J.; Bachtadse, V.; Soffel, H. New palaeomagnetic constraints on the position of Bohemia during Early Ordovician times. Geophys. J. Int. 1994, 116, 131-140. [CrossRef]

42. Tait, J.; Schatz, M.; Bachtadse, V.; Soffel, H.C. Palaeomagnetism and Palaeozoic palaeogeography of Gondwana and European terranes. In Orogenic Processes: Quantification and Modelling in the Variscan Belt; Franke, W., Haak, V., Oncken, O., Tanner, D., Eds.; Geological Society, London, Special Publications: London, UK, 2000; pp. 21-34.

43. Ruban, D.A. Lochkovian (earliest Devonian) transgressions and regressions along the "Tethyan" margin of Gondwana: A review of lithostratigraphical data. Gondwana Res. 2011, 20, 739-744. [CrossRef]

44. Haq, B.U.; Schutter, S.R. A chronology of Paleozoic sea-level changes. Science 2008, 322, 64-68. [CrossRef] [PubMed]

45. Müller, R.D.; Sdrolias, M.; Gaina, C.; Steinberger, B.; Heine, C. Long-term sea-level fluctuations driven by ocean basin dynamics. Science 2008, 319, 1357-1362. [CrossRef]

46. Sperling, E.A.; Melchin, M.J.; Fraser, T.; Stockey, R.G.; Farrell, U.C.; Bhajan, L.; Brunoir, T.N.; Cole, D.B.; Gill, B.C.; Lenz, A.; et al A long-term record of early to mid-Paleozoic marine redox change. Sci. Adv. 2021, 7, eabf4382. [CrossRef]

47. Scotese, C.R. An Atlas of Phanerozoic Paleogeographic Maps: The Seas Come In and the Seas Go Out. Annu. Rev. Earth Planet. Sci. 2021, 49, 679-728. [CrossRef]

48. Torsvik, T.H.; Cocks, L.R.M. Earth History and Palaeogeography; Cambridge University Press: Cambridge, UK, 2016 ; p. 332.

49. Servais, T. The proliferation of early Palaeozoic peri-Gondwanan terranes: The productive work of splitters. In Proceedings of the Lyell Meeting 2007, Early Palaeozoic Peri-Gondwana Terranes: New Insights from Tectonics and Biogeography, London, UK, 21 February 2007; p. 16.

50. Ferretti, A.; Oggiano, G.; Corradini, C.; Storch, P. Silurian Palaeogeography of northern Gondwana: Where was Sardinia at that time? Rend. Soc. Palaeont. Ital. 2009, 3, 67-76.

51. Harper, D.A.T.; Servais, T. Early Palaeozoic Biogeography and Palaeogeography. Geol. Soc. Mem. 2013, 38, 490. [CrossRef]

52. Stampfli, G.M.; Hochard, C.; Von Raumer, J. Reconstructing the Palaeozoic Gondwana margin and its redistribution-New aspects. Geophys. Res. Abstr. 2006, 8, 02708.

53. Von Raumer, J.F.; Stampfli, G.M. The birth of the Rheic Ocean-Early Palaeozoic subsidence patterns and subsequent tectonic plate scenarios. Tectonophysics 2008, 461, 9-20. [CrossRef]

54. Scotese, C.R. Atlas of Devonian Paleogeographic Maps; PALEOMAP Atlas for ArcGIS, 4; PALEOMAP Project: Evanston, IL, USA, 2014.

55. Renton, J.J.; Repine, T. The Devonian Period. West Va. Univ. Read. Notes 2016, 20. Available online: https://researchrepository. wvu.edu/earthscience_readings/20 (accessed on 20 October 2021).

56. Jaeger, H. Graptolites. In The Silurian-Devonian Boundary: Final Report of the Committee on the Silurian-Devonian Boundary within IUGS Commission on Stratigraphy and a State of the Art Report for Project Ecostratigraphy; Martinsson, A., Ed.; IUGS: Paris, France, 1977; Volume 5, pp. 337-345.

57. Jeppsson, L. Conodont biostratigraphy of the Silurian-Devonian boundary stratotype at Klonk, Czechoslovakia. Geol. Paleontol. 1988, 22, 21-31.

58. Carls, P.; Slavík, L.; Valenzuela-Ríos, J.I. Revisions of conodont biostratigraphy across the Silurian-Devonian boundary. Bull. Geosci. 2007, 82, 145-164. [CrossRef]

59. Walliser, O.H. Natural boundaries and Commission boundaries in the Devonian. Cour. Forsch.-Inst. Senckenberg 1985, 75, 401-408.

60. Walliser, O.H. Global events in the Devonian and Carboniferous. In Global Events and Event Stratigraphy in the Phanerozoic; Walliser, O.H., Ed.; Springer: Berlin/Heidelberg, Germany, 1996; pp. 225-250.

61. Urbanek, A. Biotic crises in the history of Upper Silurian graptoloids: A palaeobiological model. Hist. Biol. 1993, 7, 29-50. [CrossRef]

62. Manda, Š.; Frýda, J. Silurian-Devonian boundary events and their influence on cephalopod evolution: Volutionary significance of cephalopod egg size during mass extinctions. Bull. Geosci. 2010, 85, 513-540. [CrossRef]

63. Hladíková, J.; Hladil, J.; Kříbek, B. Carbon and oxygen isotope record across Př́idolí to Givetian stage boundaries in the Barrandian basin (Czech Republic). Palaeogeogr. Palaeoclimatol. Palaeoecol. 1997, 132, 225-241. [CrossRef]

64. Buggisch, W.; Mann, U. Carbon isotope stratigraphy of Lochkovian to Eifelian limestones from the Devonian of central and southern Europe. Int. J. Earth Sci. 2004, 93, 521-541. [CrossRef]

65. Ainsaar, L.; Kaljo, D.; Martma, T.; Meidla, T.; Männik, P.; Nõlvak, J.; Tinn, O. Middle and Upper Ordovician carbon isotope chemostratigraphy in Balto-scandia: A correlation standard and clues to environ-mental history. Palaeogeogr. Palaeoclimatol. Palaeoecol. 2000, 294, 189-201. [CrossRef]

66. Bergström, S.; Saltzman, M.R.; Leslie, S.A.; Ferretti, A.; Young, S.A. Trans-Atlantic application of the Baltic Middle and Upper Ordovician carbon isotope zonation. Est. J. Earth Sci. 2015, 64, 8-12. [CrossRef]

67. Saltzman, M.R. Carbon isotope $\left(\left(^{13} \mathrm{C}\right)\right.$ stratigraphy across the Silurian-Devonian transition in North America: Evidence for a perturbation of the global carbon cycle. Palaeogeogr. Palaeoclimatol. Palaeoecol. 2002, 187, 83-100. [CrossRef] 
68. Jacobi, D.J.; Barrick, J.E.; Kleffner, M.A.; Karlsson, H.R. Stable isotope chemostratigraphy and conodont biostratigraphy across the SIlurian-Devonian boundary in suthwestern Laurentia. Palaeont. Am. 2009, 63, 9-31.

69. Husson, J.M.; Schoene, B.; Bluher, S.; Maloof, A.C. Chemostratigraphic and U-Pb geochronologic constraints on carbon cycling across the Silurian-Devonian boundary. Earth Planet. Sci. Lett. 2016, 436, 108-120. [CrossRef]

70. Strauss, J.V.; Fraser, T.A.; Melchin, M.J.; Allen, T.; Malinowski, J.; Feng, X.; Taylor, J.; Day, J.; Gill, B.C.; Sperling, E.A. The Road River Group of northern Yukon, Canada: Early Paleozoic deep-water sedimentation within the Great American Carbonate Bank. Can. J. Earth Sci. 2020, 57, 1193-1219. [CrossRef]

71. Małkowski, K.; Racki, G. A global biogeochemical perturbation across the Silurian-Devonian boundary: Ocean-continentbiosphere feedbacks. Palaeogeogr. Palaeoclimatol. Palaeoecol. 2009, 276, 244-254. [CrossRef]

72. Małkowski, K.; Racki, G.; Drygant, D.; Szaniawski, H. Carbon isotope stratigraphy across the Silurian-Devonian transition in Podolia, Ukraine: Evidence for a global biogeochemical perturbation. Geol. Mag. 2009, 146, 674-689. [CrossRef]

73. Racki, G.; Baliński, A.; Wrona, R.; Małkowski, K.; Drygant, D.; Szaniawski, H. Faunal dynamics across the Silurian-Devonian positive isotope excursions $\left(\delta^{13} \mathrm{C}, \delta^{18} \mathrm{O}\right)$ in Podolia, Ukraine: Comparative analysis of the Ireviken and Klonk events. Acta Palaeontol. Pol. 2012, 57, 795-832. [CrossRef]

74. Kaljo, D.; Grytsenko, V.; Kallaste, T.; Kiipli, T.; Martma, T. Upper Silurian stratigraphy of Podolia revisited: Carbon isotopes, bentonites and biostratigraphy. GFF 2014, 136, 136-141. [CrossRef]

75. Spiridonov, A.; Stankevič, R.; Gečas, T.; Brazauskas, A.; Kaminskas, D.; Musteikis, P.; Kaveckas, T.; Meidla, T.; Bičkauskas, G.; Ainsaar, L.; et al. Ultra-high resolution multivariate record and multiscale causal analysis of Pridoli (late Silurian): Implications for global stratigraphy, turnover events, and climate-biota interactions. Gondwana Res. 2020, 86, 222-249. [CrossRef]

76. Corriga, M.G.; Corradini, C.; Lehnert, O.; Joachimski, M.M.; Pondrelli, M.; Simonetto, L. The Silurian-Devonian Boundary in the Rifugio Lambertenghi Fontana III Section (Wolayer Area, Carnic Alps, Italy); Karl-Franzens-Universität Graz: Graz, Austria, 2009; Volume 14, pp. 24-25.

77. Corradini, C.; Corriga, M.G. Silurian and lowermost Devonian conodonts from the Passo Volaia area (Carnic Alps, Italy). Boll. Soc. Paleont. Ital. 2010, 49, 237-253.

78. Slavík, L.; Hladil, J. Early Devonian (Lochkovian-early Emsian) bioevents and conodont response in the Prague Synform (Czech Republic). Palaeogeogr. Palaeoclimatol. Palaeoecol. 2020, 549, 109148. [CrossRef]

79. Cháb, J.; Breiter, K.; Fatka, O.; Hladil, J.; Kalvoda, J.; Šimůnek, Z.; Štorch, P.; Vašíček, Z.; Zajíc, J.; Zapletal, J. Stručná geologie základu Českého masivu a jeho karbonského a permského pokryvu. Vydav. České Geol. Služby. 2008, p. 284. Available online: https:/ / search.mlp.cz/cz/titul/strucna-geologie-zakladu-ceskeho-masivu-a-jeho-karbonskeho-a-permskeho-pokryvu/ 4561762/\#/getPodobneTituly=deskriptory-eq:97604239-amp:key-eq:4561762 (accessed on 20 October 2021).

80. Hajná, J.; Žák, J.; Kachlík, V.; Chadima, M. Subduction-driven shortening and differential exhumation in a Cadomian accretionary wedge: The Teplá-Barrandian unit, Bohemian Massif. Precambrian Res. 2010, 176, 27-45. [CrossRef]

81. Melichar, R. Tectonics of the Prague Synform: A hundred years of scientific discussion. Krystalinikum 2004, 30, 167-187.

82. Knížek, M.; Melichar, R.; Janečka, J. Stratigraphic separation diagrams as a tool for determining fault geometry in a folded and thrusted region: An example from the Barrandian region, Czech Republic. Geol. J. 2010, 45, 536-543. [CrossRef]

83. Vacek, F. Carbonate microfacies and depositional environments of the Silurian-Devonian boundary strata in the Barrandian area (Czech Republic). Geol. Carpathica 2007, 58, 497-510.

84. Vacek, F.; Hladil, J.; Schnabl, P. Stratigraphic correlation potential of magnetic susceptibility and gamma-ray spectrometric variations in calciturbiditic facies (Silurian-Devonian boundary, Prague Synclinorium, Czech Republic). Geol. Carpathica 2010, 61, 257-272. [CrossRef]

85. Kř́žž, J. Silurian field excursions: Prague Basin (Barrandian), Bohemia. In Geological Series; Bassett, M.G., Ed.; National Museum of Wales: Cardiff, UK, 1992; Volume 13, p. 111.

86. Chlupáč, I.; Jaeger, H.; Zikmundová, J. The Silurian-Devonian boundary in the Barrandian. Bull. Can. Pet. Geol. 1972, 20, 104-174.

87. Jeppsson, L. Latest Silurian conodonts from Klonk, Czechoslovakia. Geol. Paleontol. 1989, 23, $21-37$.

88. Slavík, L. Summary of conodont data from the GSSP of the Silurian-Devonian boundary at Klonk near Suchomasty. In International Conodont Symposium 4: Progress on Conodont Investigation, Field Guide Book; Suttner, T.J., Valenzuela-Ríos, J.I., Liao, J.-C., Corradini, C., Slavík, L., Eds.; Karl-Franzens-Universität Graz: Graz, Austria, 2017; Volume 23, pp. $192-197$.

89. Chlupáč, I.; Kř́žž, J.; Schönlaub, H.P. Field Trip E. Silurian and Devonian conodonts of the Barrandian. In Second European Conodont Symposium -ECOS II. Guidebook-Abstracts; Abhandlungen der Geologischen Bundesanstalt: Vienna, Austria, 1980; Volume 35, pp. 147-180.

90. Kř́̌̌ž, J.; Jaeger, H.; Paris, F.; Schönlaub, H.P. Př́idolí-The fourth subdivision of the Silurian. Jahrb. Geol. B. 1986, 129, 291-360.

91. Slavík, L. Lanea carlsi conodont apparatus reconstruction and its significance for subdivision of the Lochkovian. Acta Palaeontol. Pol. 2011, 56, 313-327. [CrossRef]

92. Slavík, L.; Carls, P.; Hladil, J.; Koptíková, L. Subdivision of the Lochkovian Stage based on conodont faunas from the stratotype area (Prague Synform, Czech Republic). Geol. J. 2012, 47, 616-631. [CrossRef]

93. Gouwy, S.; Corradini, C. Graphic correlation of the Sardinian Ockerkalk (Upper Silurian): Implications on the conodont biostratigraphy. GFF 2006, 128, 103-108. [CrossRef]

94. Hušková, A.; Slavík, L. Morphologically distinct P1 elements of Zieglerodina (Conodonta) at the Silurian-Devonian boundary: Review and correlation. Bull. Geosci. 2021, 96, 327-340. [CrossRef] 
95. Corriga, M.G.; Corradini, C.; Pondrelli, M.; Schönlaub, H.-P.; Nozzi, L.; Todesco, R.; Ferretti, A. Uppermost Ordovician to lowermost Devonian conodonts from the Valentintörl section and comments on the post Hirnantian hiatus in the Carnic Alps. Newsl. Stratigr. 2021, 54, 183-207. [CrossRef]

96. Becker, R.T.; El Hassani, H. Devonian to Lower Carboniferous stratigraphy and facies of the Moroccan Meseta: Implication for palaeogeography and structural interpretation. A project outline. In Devonian to Lower Carboniferous Stratigraphy and Facies of the Western Meseta: Implications for Palaeogeography and Structural Interpretation; Becker, R.T., El Hassani, H., Aboussalam, S.Z., Eds.; Hassan II Academy of Science and Technology: Rabat, Morocco, 2020; Volume 10, pp. 9-25.

97. Charriére, A.; Regnault, S. Stratigraphie du Dévonien de la boutonnière d'Immouzer-du-Kandar (Sud de Fèz). Conséquences paléogeographiques. Notes Mem. Serv. Géol. Maroc 1989, 335, 25-35.

98. Benfrika, M.; Bultynck, P.; El Hassani, A. Upper Silurian to Middle Devonian conodont faunas from the Rabat-Tiflet area (north western Moroccan Meseta). Geol. Q. 2007, 51, 393-406.

99. El Hassani, H. La Zone de Rabat-Tiflet: Bordure nord de la chaine calédono-hercynienne du Maroc. Bull. Inst. Sci. 1990, $18,134$.

100. Hollard, H. Le domaine de l'Anti-Atlas au Maroc. In The Silurian-Devonian Boundary; Martinsson, A., Ed.; IUGS: Pairs, France, 1977; Volume 5, pp. 168-194.

101. Haude, R.; Walliser, O.H. Conodont-based Upper Silurian-Lower Devonian range of scyphocrinoids in SE Morocco. In Proceedings of the 6th International Graptolite Conference and 1998 Field Meeting IUGS Subcommission on Silurian Stratigraphy; Gutiérrez-Marco, J.C., Rábano, I., Eds.; Instituto Tecnologico Geominero de España: Madrid, Spain, 1998; Volume 23, pp. 94-96.

102. Belka, Z.; Klug, K.; Kaufmann, B.; Korn, D.; Döring, S.; Feist, R.; Wendt, J. Devonian condont and ammonoid succession of eastern Tafilalt (Ouidane Chebbi section), Anti-Atlas, Morocco. Acta Geol. Pol. 1999, 49, 1-23.

103. Carls, P. Spain. In The Silurian-Devonian Boundary: Final Report of the Committee on the Silurian-Devonian Boundary within IUGS Commission on Stratigraphy and a State of the Art Report for Project Ecostratigraphy; Martinsson, A., Ed.; IUGS: Pairs, France, 1977; Volume 5, pp. 143-158.

104. Carls, P.; Valenzuela-Ríos, J.I. Devonian-Carboniferous rocks from the Iberian Cordillera. In Palaeozoic Conodonts from Northern Spain, Eight International Conodont Symposium Held in Europe; García-López, S., Bastida, F., Eds.; Instituto Tecnologico Geominero de España: Madrid, Spain, 2002; Volume 1, pp. 299-314.

105. Savage, J.F.; Boschma, D. Geological maps of the Southern Cantabrian Mountains (Spain). Leidse Geol. Meded. 1980, 50, 75-114.

106. García-López, S.; Jahnke, H.; Sanz-López, J. Uppermost Pridoli to Upper Emsian stratigraphy of the Alto Carrión Unit, Palentine Domain (Northwest Spain). In Palaeozoic Conodonts from Northern Spain, Eight International Conodont Symposium Held in Europe; García-López, S., Bastida, F., Eds.; Instituto Tecnologico Geominero de España: Madrid, Spain, 2002; Volume 1, pp. $229-257$.

107. Valenzuela-Ríos, J.I. The Lower Devonian conodont Pedavis pesavis and the pesavis Zone. Lethaia 1994, 27, 199-207. [CrossRef]

108. Valenzuela-Ríos, J.I. Silurian-Devonian Interval in the Caballé-1 section. In International Conodont Symposium 4: Progress on Conodont Investigation, Field Guide Book; Suttner, T.J., Valenzuela-Ríos, J.I., Liao, J.-C., Corradini, C., Slavík, L., Eds.; Karl-FranzensUniversität Graz: Graz, Austria, 2017; Volume 23, pp. 37-39.

109. Degardin, J.M. Le Silurien des Pyrénées, Biostratigraphie, Paléogéographie. Soc. Géol. Nord 1988, 15, 1-525.

110. Valenzuela-Ríos, J.I.; Liao, J.-C. Wenlock-Pridoli (Silurian) strata in the Llesui section. In International Conodont Symposium 4: Progress on Conodont Investigation, Field Guide Book; Suttner, T.J., Valenzuela-Ríos, J.I., Liao, J.-C., Corradini, C., Slavík, L., Eds.; Karl-Franzens-Universität Graz: Graz, Austria, 2017; Volume 23, pp. 106-108.

111. Valenzuela-Ríos, J.I. Wenlock to Lochkovian strata in the Esera 3 section. In International Conodont Symposium 4: Progress on Conodont Investigation, Field Guide Book; Suttner, T.J., Valenzuela-Ríos, J.I., Liao, J.-C., Corradini, C., Slavík, L., Eds.; Karl-FranzensUniversität Graz: Graz, Austria, 2017; Volume 23, pp. 40-42.

112. Girard, C.; Cornnée, J.-J.; Corradini, C.; Fravalo, A.; Feist, R. Palaeoenvironmental changes at Col des Tribes (Montagne Noire, France), a reference section for the Famennian of North Gondwana-related areas. Geol. Mag. 2014, 151, 864-884. [CrossRef]

113. Feist, R. The Palaeozoic of the Montagne Noire, Southern France. IGCP 421: North Gondwana mid-Palaeozoic Biodynamics and ECOS VIII: 8th European Conodont Symposium. In Guidebook of the Field Excursion; Weliy: Hoboken, NJ, USA, $2002 ;$ pp. 1-82.

114. Feist, R.; Schönlaub, H.-P. Le passage siluro-dévonien dans la Montagne Noire orientale. C. R. Acad. Sci. Paris 1973, 276, 1267-1269.

115. Feist, R.; Schönlaub, H.-P. Zur Silur/Devon-Grenze in der östlichen Montagne Noire Süd-Frankreichs-The Silurian/Devonian boundary in the eastern Montagne Noire (Southern France). N. J. Geol. Paläont. Mh. 1974, 4, 200-219.

116. Feist, R. Devonian Stratigraphy of the southeastern Montagne Noire (France). In Devonian Series Boundaries-Results of World-Wide Studies; Ziegler, W., Werner, R., Eds.; Courier Forschungsinstitut Senckenberg: Frankfurt, Germany, 1985; Volume 75, pp. 331-352.

117. De Bock, F. Présence de Chitinozoaires dans le passage siluro-dévonien de la Montagne Noire sud-orientale. Geobios 1982, 15, 845-871. [CrossRef]

118. Serventi, P.; Feist, R. Silurian nautiloid cephalopods from the Cabriéres area (Montagne Noire, France): A preliminary report. Rend. Soc. Paleont. Ital. 2009, 3, 341.

119. Carmignani, L.; Pertusati, P.C. Analisi strutturale di un segmento della catena ercinica: Il Gerrei (Sardegna sud-orientale). Boll. Soc. Geol. Ital. 1979, 96, 339-364.

120. Ferretti, A.; Serpagli, E. Geological outline, community sequence and paleoecology of the Silurian of Sardinia. Riv. Ital. Paleont. Strat. 1996, 102, 353-362.

121. Ferretti, A.; Corradini, C.; Serpagli, E. The Silurian and Devonian sequence in SW Sardinia. Giorn. Geol. 1998, 60, 57-61. 
122. Corradini, C.; Ferretti, A.; Serpagli, E.; Barca, S. The Ludlow-Pridoli Section "Genna Ciuerciu” west of Silius. Giorn. Geol. 1998, 60, 112-118.

123. Corradini, C.; Corriga, M.G.; Ferretti, A.; Leone, F. The Silurian of the Foreland Zone (southwestern Sardinia). Rend. Soc. Palaeont. Ital. 2009, 3, 51-56.

124. Corradini, C.; Ferretti, A. The Silurian of the External Nappes (southeastern Sardinia). Rend. Soc. Palaeont. Ital. $2009,3,43-49$.

125. Barca, S.; Corradini, C.; Ferretti, A.; Olivieri, R.; Serpagli, E. Conodont biostratigraphy of the "Ockerkalk" (Silurian) from Southestern Sardinia. Riv. Ital. Paleont. Strat. 1995, 100, 459-476.

126. Corradini, C.; Olivieri, R. Conodont biostratigraphy of some supplementary sections in the Sardinian "Ockerkalk" (Upper Silurian). Boll. Mus. Reg. Sci. Nat. Torino 1997, 15, 89-100.

127. Corradini, C.; Ferretti, A.; Corriga, M.G.; Serpagli, E. Loboliths (crinoids) and conodont biostratigraphy of the Genna Ciuerciu Section (SE Sardinia). Rend. Soc. Palaeont. Ital. 2009, 3, 217-224.

128. Corradini, C.; Ferretti, A.; Corriga, M.G.; Serpagli, E. The reference section of the Sardinian Ockerkalk: The Silius Section. Rend. Soc. Palaeont. Ital. 2009, 3, 209-216.

129. Serpagli, E.; Corradini, C.; Ferretti, A. Conodonts from a Ludlow-Pridoli section near the Silius Village. Giorn. Geol. 1998, 60, 104-111.

130. Corriga, M.G. Biostratigrafia a Conodonti Attorno al Limite Siluriano-Devoniano in Alcune Aree del Nord Gondwana. Ph.D. Thesis, University of Cagliari, Cagliari, Italy, 2011; p. 152.

131. Barca, S.; Ferretti, A.; Massa, P.; Serpagli, E. The Hercynian Arburese Tectonic Unit of SW Sardinia. New stratigraphic and structural data. Riv. Ital. Paleont. Strat. 1992, 98, 119-136.

132. Corradini, C.; Ferretti, A.; Serpagli, E. Wenlock and Pridoli conodonts from Argiola, East of Domusnovas. Giorn. Geol. 1998, 60, 194-198.

133. Corriga, M.G.; Corradini, C. Nuovi dati sulla sequenza Siluriano-Devoniana della Sardegna sud-occidentale. Rend. Online Soc. Geol. Ital. 2008, 3, 262-263.

134. Ferretti, A.; Štorch, P.; Corradini, C. The Silurian of Sardinia: Facies development and palaeoecology. Rend. Soc. Palaeont. Ital. 2009, 3, 57-66.

135. Serpagli, E.; Mastandrea, A. Conodont assemblages from the Silurian-Devonian boundary beds of southwestern Sardinia (Italy). N. J. Geol. Paläont. Mh. 1980, H1, 37-42. [CrossRef]

136. Corradini, C.; Ferretti, A.; Serpagli, E. An Early Devonian section near Fluminimaggiore (Galemmu). Giorn. Geol. 1998, 60, 168-174.

137. Gnoli, M.; Leone, F.; Olivieri, R.; Serpagli, E. The Mason Porcus Section as reference section for Uppermost Silurian-Lowermost Devonian in SW Sardinia. Boll. Soc. Paleont. Ital. 1988, 27, 323-334.

138. Olivieri, R.; Serpagli, E. Latest Silurian-early Devonian conodonts from Mason Porcus Section near Fluminimaggiore, Southwestern Sardinia. Boll. Soc. Paleont. Ital. 1990, 29, 59-76.

139. Corradini, C.; Serpagli, E. A Late Llandovery-Pridoli (Silurian) conodont biozonation in Sardinia. Giorn. Geol. 1998, 60, 85-88.

140. Corriga, M.G.; Corradini, C.; Ferretti, A. Silurian conodonts from Sardinia: An overview. Rend. Soc. Palaeont. Ital. 2009, 3, 95-107.

141. Corradini, C.; Pondrelli, M.; Simonetto, L.; Corriga, M.G.; Spalletta, C.; Suttner, T.J.; Kido, E.; Mossoni, A.; Serventi, P. Stratigraphy of the La Valute area (Mt. Zermula massif, Carnic Alps, Italy). Boll. Soc. Paleont. Ital. 2016, 55, 55-78.

142. Corradini, C.; Pondrelli, M. The Pre-Variscan Sequence of the Carnic Alps (Italy-Austria). Geol. Field Trips Maps 2021, $13,71$. [CrossRef]

143. Schönlaub, H.-P. Paläozoikum in Österreich. Verbreitung, Stratigraphie, Korrelation, Entwicklung und Palaogeographie nichtmetamorpher und metamorpher Abfolgen. Abh. Geol. B.-A. 1979, 33, 1-124.

144. Schönlaub, H.P. Carnic Alps. Field Trip A. In Second European Conodont Symposium (ECOS II), Guidebook, Abstracts; Schönlaub, H.P., Ed.; Geological Survey of Austria: Vienna, Austria, 1980; Volume 35, pp. 5-57.

145. Wenzel, B. Isotopenstratigraphische Untersuchnungen an silurischen Abfolgen und deren paläozeanographische Interpretazion. Erlanger Geol. Abh. 1997, 129, 1-117.

146. Corradini, C.; Pondrelli, M.; Serventi, P.; Simonetto, L. The Silurian cephalopod limestone in the Monte Cocco area (Carnic Alps, Italy): Conodont biostratigraphy. Rev. Española Micropaleontol. 2003, 35, $285-294$.

147. Corradini, C.; Corriga, M.G.; Pondrelli, M.; Serventi, P.; Simonetto, L. Il Siluriano di Monte Cocco (Alpi Carniche). Gortania Geol. Paleontol. Paletnol. 2010, 31, 23-30.

148. Corradini, C.; Suttner, T.J. The Pre-Variscan sequence of the Carnic Alps (Austria and Italy); Geological Survey of Austria: Vienna, Austria, 2015; Volume 69, p. 158.

149. Ferretti, A.; Schönlaub, H.P.; Corradini, C.; Corriga, M.G.; Pondrelli, M.; Simonetto, L.; Serventi, P. Alticola Formation. In The Pre-Variscan Sequence of the Carnic Alps (Austria and Italy); Corradini, C., Suttner, T.J., Eds.; Geological Survey of Austria: Vienna, Austria, 2015; Volume 69, pp. 56-60.

150. Suttner, T.J.; Bandel, K.; Corradini, C.; Corriga, M.G.; Kido, E.; Pohler, S.M.L.; Pondrelli, M.; Schönlaub, H.P.; Simonetto, L.; Vai, G.B. Seekopf Formation. In The Pre-Variscan Sequence of the Carnic Alps (Austria and Italy); Corradini, C., Suttner, T.J., Eds.; Geological Survey of Austria: Vienna, Austria, 2015; Volume 69, pp. 69-72. 
151. Schönlaub, H.P.; Ferretti, A.; Corradini, C.; Corriga, M.G.; Pondrelli, M.; Simonetto, L. Nölbling Formation. In The Pre-Variscan Sequence of the Carnic Alps (Austria and Italy); Corradini, C., Suttner, T.J., Eds.; Geological Survey of Austria: Vienna, Austria, 2015; Volume 69, pp. 61-64.

152. Schönlaub, H.P.; Ferretti, A.; Corradini, C.; Corriga, M.G.; Pondrelli, M.; Simonetto, L. Bischofalm Formation. In The Pre-Variscan Sequence of the Carnic Alps (Austria and Italy); Corradini, C., Suttner, T.J., Eds.; Geological Survey of Austria: Vienna, Austria, 2015; Volume 69, pp. 65-68.

153. Corradini, C.; Corriga, M.G.; Pondrelli, M.; Schönlaub, H.P.; Simonetto, L.; Spalletta, C.; Ferretti, A. Rauchkofel Formation. In The Pre-Variscan Sequence of the Carnic Alps (Austria and Italy); Corradini, C., Suttner, T.J., Eds.; Geological Survey of Austria: Vienna, Austria, 2015; Volume 69, pp. 73-76.

154. Suttner, T.J. Conodont stratigraphy, facies-related distribution patterns and stable isotopes (carbon and oxygen) of the uppermost Silurian to lower Devonian Seewarte section (Carnic Alps, Carinthia, Austria). Abh. Geol. B.-A. 2007, 59, 1-111.

155. Corriga, M.G.; Corradini, C.; Schönlaub, H.P.; Pondrelli, M. Lower Lochkovian (Lower Devonian) conodonts from Cellon section (Carnic Alps, Austria). Bull. Geosci. 2016, 91, 261-270. [CrossRef]

156. Schönlaub, H.P. Devonian conodonts from section Oberbuchach II in the Carnic Alps (Austria). Cour. Forsch.-Inst. Senckenberg $1985,75,353-374$.

157. Schönlaub, H.P.; Corradini, C.; Corriga, M.G. Devonian conodonts from the Oberbuchach II section. In International Conodont Symposium 4: Progress on Conodont Investigation, Field Guide Book; Suttner, T.J., Valenzuela-Ríos, J.I., Liao, J.-C., Corradini, C., Slavík, L., Eds.; Karl-Franzens-Universität Graz: Graz, Austria, 2017; Volume 23, pp. 280-285.

158. Jaeger, H.; Schönlaub, H.P. Silur und Devon nördlich der Gundersheimer Alm in den Karnischen Alpen (Österreich). Carinthia II 1980, 403-444.

159. Schönlaub, H.P.; Corradini, C. Conodonts and graptolites from the Oberbuchach I and Oberbuchach Ib sections (KatianLochkovian). In International Conodont Symposium 4: Progress on Conodont Investigation, Field Guide Book; Suttner, T.J., ValenzuelaRíos, J.I., Liao, J.-C., Corradini, C., Slavík, L., Eds.; Karl-Franzens-Universität Graz: Graz, Austria, 2017; Volume 23, pp. $276-279$.

160. Corradini, C.; Corriga, M.G.; Pondrelli, M.; Serventi, P.; Simonetto, L.; Ferretti, A. Lochkovian (Lower Devonian) marine-deposits from the Rio Malinfier West section (Carnic Alps, Italy). Ital. J. Geosci. 2019, 138, 153-170. [CrossRef]

161. Corriga, M.G.; Corradini, C. Silurian-Lower Devonian conodonts from the Rifugio Lambertenghi Fontana III (RLF III) Section (Carnic Alps, Italy). Rend. Soc. Palaeont. Ital. 2009, 3, 275.

162. Hubmann, B.; Gross, M. The vicinity of Graz: Upper Silurian to upper Carboniferous of the Graz Palaeozoic, upper Cretaceous of the Kainach Gosau and middle Miocene of Gratkorn. Ber. Geol. B.-A. 2015, 111, 41-74.

163. Schönlaub, H.P. The Silurian of Austria. Ber. Geol. B.-A. 1997, 40, $20-41$.

164. Ebner, F. Das Silur/Devon Vorkommen von Eggenfeld—Ein Beitrag zur Biostratigraphie des Grazer Paläozoikum. Mitt. Abt. Geol. Paläontol. Bergbau Landesmus. Joanneum Graz 1976, 37, 275-305.

165. Ebner, F. Silurian/Devonian boundary section/Palaeozoic of Graz. Ber. Geol. B.-A. 1994, 30, 75-82.

166. Suttner, T.J.; Lukeneder, A. Accumulation of late Silurian serpulid tubes and their palaeoecological implications (Blumau Formation; Burgenland; Austria). Ann. Nat. Mus. Wien 2004, 105A, 175-187.

167. Suttner, T.J. Lower Devonian conodonts from the "Baron von Kottwitz" quarry (southern Burgenland, Austria). Palaeontogr. Am. $2009,62,75-87$

168. Schönlaub, H.P.; Meco, S. Lower Palaeozoic Conodonts from Albania. Jb. Geol. B.-A. 1986, 128, $439-447$.

169. Meco, S. Litho-biostratigraphy and the conodonts of Palaeozoic/Triassic deposits in Albania. Palaeontogr. A 2010, 292, 131-197. [CrossRef]

170. Spassov, C.H. Stratigraphie des Devons in Sudwest-Bulgarien. Bull. Geol. Inst. Ser. Stratigr. Lithol. 1973, $22,5-39$.

171. Spassov, C.H. Die Conodontenchronologie aus Unterdevons im Mittelteil der Balkanhalbinsel. Proc. Geol. Inst. Ser. Stratigr. Lithol. 1971, 20, 5-14

172. Boncheva, I. Conodonts from Vrabcha Formation (Devonian) in Kraishte area, Southwest Bulgaria (in Bulgarian with English abstract). Rev. Bulg. Geol. Soc. 1987, 48, 117-125.

173. Boncheva, I. Conodont biostratigraphy of the Lower Devonian in South west Bulgaria. Geol. Balc. 1991, $21,55-72$.

174. Boncheva, I.; Sachanski, V.; Lakova, I.; Yaneva, M. Facies transition and biostratigraphic correlation of the Upper Silurian and Lower Devonian in West Bulgaria. Geol. Q. 2007, 51, 407-418.

175. Sachanski, V.V.; Boncheva, I.; Lakova, I. A continuous section across the Silurian-Devonian boundary in the Kraishte region: Graptolite and conodont biostratigraphy. In Proceedings of the Jubilee International Conference "80 Years Bulgarian Geological Society", Sofia, Bulgaria, 17-18 November 2005; pp. 18-20.

176. Sachanski, V.V. Biostratigraphical subdivision of the Lower Devonian in West Bulgaria. Rev. Bulg. Geol. Soc. 1996, 57, 53-56.

177. Yalçin, M.N.; Yilmaz, I. Devonian in Turkey-A review. Geol. Carpathica 2010, 61, 235-253. [CrossRef]

178. Yilmaz, E.; Duran, O. Nomenclature of autochthonous and allochthonous units in southeastern Anatolia 'Lexicon'. Türkiye Pet. Anon. Ortaklıgı Arastırma Merk. Grubu Baskanl. Egit. Yayınları 1997, 31, 1-460. (In Turkish) 
179. Luppold, F.W.; Brocke, R.; Doyen, C.; Mann, U. Silurian-Devonian Boundary in SE Anatolia (2): Present stage for the biostratigraphic positioning of the boundary based on brachiopods, conodonts, ostracods and palynomorphs at the Hazro area. In Palaeozoic of Northern Gondwana and Its Petroleum Potential. A Field Workshop, Kayseri, Turkey, 9-14 September 2012. Extended Abstracts; Yalçın, M.N., Corbacioglu, H., Aksu, O., Bozdoğan, N., Eds.; European Association of Geoscientists \& Engineers: Houten, The Netherlands, 2012; Volume 6, pp. 111-113.

180. Gourvennec, R.; Hoşgör, İ. Brachiopods and crinoids from the Middle-Upper Devonian boundary beds in the Darende-Gürün and Van-Zincirkıran areas (Eastern Taurus, Turkey). Bull. Geosci. 2015, 90, 577-600. [CrossRef]

181. Özkan, R.; Vachard, D. A new early Frasnian (Late Devonian) foraminifer from eastern Taurides (Turkey): Evolutionary and palaeobiogeographic implications. Rev. Micropaléontol. 2015, 58, 267-282. [CrossRef]

182. Göncüoğlu, M.C.; Göncüoğlu, V.; Kozur, H.W.; Kozlu, H. Paleozoic stratigraphy of the Geyik Daği unit in the Eastern Taurides (Turkey): New age data and implications for Gondwanan evolution. Geol. Carpathica 2004, 55, 433-447.

183. Corriga, M.G.; Corradini, C. The conodont apparatus of Zieglerodina eladioi (Valenzuela Rios, 1994). Boll. Soc. Paleont. Ital. 2019, 58, 181-185.

184. Göncüoğlu, M.C.; Kozur, H. Early Devonian transgression in the Eastern Antalya Nappes: Conodont data from the Tahtalidag Nappe, north of Alanya, southern Turkey. Rec. West. Aust. Mus. 2000, 58, 279-292.

185. Yilmaz, I.O.; Göncüoğlu, M.C.; Demiray, D.G.; Gedik, İ. An approach to paleoclimatic conditions for Devonian (upper Lochkovian and middle Givetian) ironstone formation, NW Anatolian carbonate platform. Turk. J. Earth Sci. 2015, 24, 21-38. [CrossRef]

186. Sachanski, V.; Göncüoğlu, M.C.; Gedik, İ. Late Telychian (Early Silurian) graptolitic shales and the maximum Silurian highstand in the NW Anatolian Palaeozoic terranes. Palaeogeogr. Palaeoclimatol. Palaeoecol. 2010, 291, 419-428. [CrossRef]

187. Kozlu, H.; Göncüoğlu, Y.; Sarmiento, G.; Göncüoğlu, M.C. First finding of Late Silurian conodonts from the “Orthoceras Limestone", Çamdağ area, NW Turkey: Preliminary constraints for the paleogeography. Geol. Balc. 2002, 32, 3-12.

188. Boncheva, I.; Göncüoğlu, M.C.; Leslie, S.A.; Lakova, I.; Sachanski, V.; Saydam, G.; Gedik, I.; Konigshof, P. New conodont andpalynological data from the Lower Palaeozoic in Northern Çamdağ, NW Anatolia, Turkey. Acta Geol. Pol. 2009, 59, 157-171.

189. Mestre, A.; Gómez, M.; Garcías, Y.; Corradini, C.; Heredia, S. Advances on Silurian-Devonian conodont biostratigraphy in the Central Precordillera, Argentina. Cuad. Mus. Geomin. 2017, 22, 105-108.

190. Gómez, M.J.; Mestre, A.; Garcías, Y.; Corradini, C. First documentation of the Polygnathoides siluricus conodont Zone (Ludfordian) in South America (Argentina) and the stratigraphic significance of the younger species of Kockelella (Conodonta). Geol. J. 2019, 54, 3455-3467. [CrossRef]

191. Gómez, M.J.; Mestre, A.; Corradini, C.; Heredia, S. A new species, Ozarkodina huenickeni, from the upper Silurian-Lower Devonian in San Juan Precordillera, South America. J. S. Am. Earth Sci. 2021, 108, 103174. [CrossRef]

192. Cuerda, A.J. Sobre las graptofaunas del Silúrico de San Juan, Argentina. Ameghiniana 1969, 6, $223-235$.

193. Astini, R.; Piovano, E. Facies de plataforma terrígenas del Silúrico de la Plataforma sanjuanina. Rev. Asoc. Argent. 1992, 47, 99-110.

194. Astini, R.; Maretto, H. Análisis estratigráfico del Silúrico de la Precordillera Central de San Juan y consideraciones sobre la evolución de la cuenca. In Proceedings of the XIII Congreso Geológico Argentino y III Congreso de Exploración de Hidrocarburos, Buenos Aires, Argentina, 13-18 October 1996; Volume I, pp. 351-368.

195. Mestre, A.; Gómez, M.; Heredia, S.; Moreno, F. Estratigrafía del Paleozoico Inferior de la Sierra de Las Crucecitas, Precordillera Central, San Juan. Ser. Corr. Geol. 2021, 37, 5-18.

196. León, L.I.; Pereyra, M.E.; Kaufmann, C.; Astorga, A.; García, G.; Campos, M.; De Arriba, J.; Gil Crescentino, V.; Amat, P. Características estratigráficas e icnológicas de Grupo Tucunuco en la Quebrada Poblete Norte, área de Talacasto, Precordillera Central. Actas Geol. Lilloana 2016, 28, 106-112.

197. Simpson, A. Silurian conodont biostratigraphy in Australia: A review and critique. Cour. Forsch.-Inst. Senckenberg 1995, 182, 325-345.

198. Simpson, A. Silurian to basal Devonian conodonts from the Broken River Crossing, northern Australia. Rec. West. Aust. Mus. Suppl. 2000, 58, 145-162.

199. Farrell, J.R. Siluro-Devonian Conodonts from the Camelford Limestone, Welligton, New South Wales, Australia. Palaeontology 2004, 47, 937-982. [CrossRef]

200. Farrell, J.R. Late Pridoli, Lochkovian and early Pragian conodont from the Gap area between Larras Lee and Eurimbla, central western NSW, Australia. Cour. Forsch.-Inst. Senckenberg 2003, 245, 107-181.

201. Barrick, J.E.; Sundgren, J.R.; Macadams, N.E.B. Endemic earliest Lochkovian species of Caudicriodus (conodont) from southern Laurentia and the Silurian-Devonian boundary. Pap. Palaeontol. 2021, 7, 1585-1600. [CrossRef]

202. Bełka, Z.; Narckiewicz, M. Devonian. In The Geology of Central Europe, Volume 1: Precambrian and Palaeozoic; McCann, T., Ed.; The Geological Society: London, UK, 2008; pp. 383-410.

203. Verniers, J.; Maletz, J.; Kriz, J.; Zigaite, Z.; Paris, F.; Schönlaub, H.P.; Wrona, R. Silurian. In The Geology of Central Europe, Volume 1: Precambrian and Palaeozoic; McCann, T., Ed.; The Geological Society: London, UK, 2008; pp. 249-302.

204. Austin, R.L.; Orchard, M.J.; Stewart, I.J. Conodonts of the Devonian System of Great Britain. In A Stratigraphical Index of Conodonts; Higgins, A.C., Austin, R.L., Eds.; British Micropalaeontological Society: Nottingham, UK, 1985; Volume 93-166, pp. $242-249$.

205. Mashkova, T.V. Some Conodonts of the Borshchiv and Chortkiv Horizons of the Podolia. In Stratigrafiâ Nižnego Paleozoâ Centralnoj Evropy: Meždunarodnyj Geologičeskij Congress; Sokolov, B.S., Ed.; Nauka: Moscow, Russia, 1968; pp. 145-148. (In Russian)

206. Mashkova, T.V. On the range of the woschmidti Zone in Podolia. Doklady AN SSSR 1970, 190, 654-657. (In Russian) 
207. Mashkova, T.V. Zonal conodont assemblages from boundary beds of the Silurian and Devonian of Podolia. In Granica Silura $i$ Devona i Biostratigrafiâ Silura; Nalivkin, D.V., Ed.; Trudy III Meždunarodnogo Simpozûma: Leningrad, Russia, 1971; Volume 1, pp. 157-164. (In Russian)

208. Drygant, D.M. Simple Silurian and Lower Devonian conodonts from the Volyn-Podolia. Paleontol. Sb. 1974, 10, 64-70. (In Russian)

209. Drygant, D.M. Korrelaciâ i Konodonty Silurijskih-Nižniedevonskih Otloženij Volyno-Podolii; Naukova Dumka: Kiev, Ukraine, 1984; p. 192.

210. Drygant, D.M. Devonian Conodonts from South-West Margin of the East European Platform (Volyn'-Podolian Ukraine); Academperiodyka: Kiev, Ukraine, 2010; p. 156. (In Ukrainian)

211. Drygant, D.; Szaniawksi, H. Lochkovian conodonts from Podolia, Ukraine, and their stratigraphic significance. Acta Palaeontol. Podol. 2012, 57, 833-861. [CrossRef]

212. Eriksson, M.; Calner, M. The Dynamic Silurian Earth. Rapp. Medd. 2004, 121, 1-99.

213. Männik, P. The Silurian System in Estonia. In 4th Annual Meeting of IGCP 591, Estonia, 10-19 June 2014. Abstracts and Field Guide; Bauert, H., Hints, O., Meidla, T., Männik, P., Eds.; University of Tartu: Tartu, Estonia, 2014; pp. 123-128.

214. Poldvere, A. The Devonian System in Estonia. In 4th Annual Meeting of IGCP 591, Estonia, 10-19 June 2014. Abstracts and Field Guide; Bauert, H., Hints, O., Meidla, T., Männik, P., Eds.; University of Tartu: Tartu, Estonia, 2014; pp. 129-130. 